\title{
Rates of swim bladder parasite infection and PIT tag retention in upstream migrant American eels of the upper Potomac River drainage
}

Jennifer L. Zimmerman

West Virginia University

Follow this and additional works at: https://researchrepository.wvu.edu/etd

\section{Recommended Citation}

Zimmerman, Jennifer L., "Rates of swim bladder parasite infection and PIT tag retention in upstream migrant American eels of the upper Potomac River drainage" (2008). Graduate Theses, Dissertations, and Problem Reports. 4435.

https://researchrepository.wvu.edu/etd/4435

This Thesis is protected by copyright and/or related rights. It has been brought to you by the The Research Repository @WVU with permission from the rights-holder(s). You are free to use this Thesis in any way that is permitted by the copyright and related rights legislation that applies to your use. For other uses you must obtain permission from the rights-holder(s) directly, unless additional rights are indicated by a Creative Commons license in the record and/ or on the work itself. This Thesis has been accepted for inclusion in WVU Graduate Theses, Dissertations, and Problem Reports collection by an authorized administrator of The Research Repository @ WVU. For more information, please contact researchrepository@mail.wvu.edu. 
Rates of Swim Bladder Parasite Infection and PIT Tag Retention in Upstream Migrant American Eels of the Upper Potomac River Drainage

Jennifer L. Zimmerman

\begin{abstract}
Thesis Submitted to the Davis College of Agriculture, Forestry, and Consumer Sciences in partial fulfillment of the requirements

for the degree of
\end{abstract}

Master of Science

in

Wildlife and Fisheries Resources

\author{
Stuart A. Welsh, Ph.D., Chair \\ J. Todd Petty, Ph.D. \\ Kenneth Oliveira, Ph.D.
}

Division of Forestry and Natural Resources

Morgantown, WV
2008

Keywords: American eel, Anguillicola crassus, swim bladder degenerative index, PIT tag retention, Shenandoah River 


\section{Abstract}

Rates of Swim bladder Parasite Infection and PIT Tag Retention in Upstream Migrant American Eels of the Upper Potomac River Drainage

\section{Jennifer L. Zimmerman}

This thesis involved two components: identification of the parasite Anguillicola crassus in American eels, Anguilla rostrata and PIT tag retention in eels in a laboratory setting. The recent spread of the swim bladder nematode parasite, Anguillicola crassus, in American eels has caused concern among biologists and fishery managers. A total of 244 yellow-phase American eels were collected at the Millville Dam eel ladder on the Shenandoah River, WV. Swim bladders were removed and examined for the presence of the nematode parasite. The number of parasites in each eel was recorded, and prevalence, intensity, and mean intensity were calculated. A swim bladder degenerative index (SDI) was also used on a subsample of 50 eels to document previous infections and the health state of the swim bladder. Prevalence of the parasite was $2 \%$, and both intensity and mean intensity were 1 . Based on the SDI, $38 \%$ of the eels showed signs of a previous infection of $A$. crassus. None of the eels from the Shenandoah River had severely degraded swim bladders, $38 \%$ had moderately damaged swim bladders, and $62 \%$ had healthy swim bladders. This is the first study that confirms the presence of $A$. crassus in the Potomac River watershed and the first to document the parasite in West Virginia. For the second part of the thesis, retention rates of passive integrated transponders (PIT tags) were compared among three tagging locations of small (205-370 $\mathrm{mm}$ ) American eels: the dorsal musculature behind the head, the dorsal musculature near the dorsal fin origin, and the abdominal cavity. Eighteen American eels from the Shenandoah River, WV were PIT tagged in the three locations and tag retention was measured for a total of 9 weeks. Tag retention was highest in the dorsal musculature $(100 \%)$ and in the abdominal cavity $(100 \%)$, and lowest behind the head $(88 \%)$. These results are consistent with previous literature. This research was a pilot study to determine PIT tag placement for a study of upstream migration in American eels. 


\section{Dedication}

To my husband, Mike, and son, Kelvin, for all the love and joy that they have brought to my life, and to my mom and sister for their continual support and help in making me who I am today 


\section{Acknowledgements}

I would like to extend thanks to my graduate committee, especially Dr. Stuart Welsh for his guidance, Dr. Todd Petty, and Dr. Ken Oliveira, for their contributions both to this project and my various learning experiences throughout the past two years.

A special thanks to Ken Oliveira for his time in teaching me otolith ageing techniques. I would also like to thank Evelyn Michael for her assistance in the lab, Alison Mynsberge for helping me tinker with the isomet saw, and Ken Sheehan and Dustin Smith for their help in the field.

Also, thank you all my professors and Committee members for being so supportive and working with me through my pregnancy, and for all the wonderful opportunities they provided me throughout my time at WVU. Thank you to Becky Nestor for all her assistance and support.

A final thanks to my mother-in-law, Patty. Without her many hours of help with Kelvin, I would never have finished my thesis in a timely fashion.

Funding was provided by Allegheny Energy Supply and the West Virginia Division of Natural Resources. 


\section{Table of Contents}

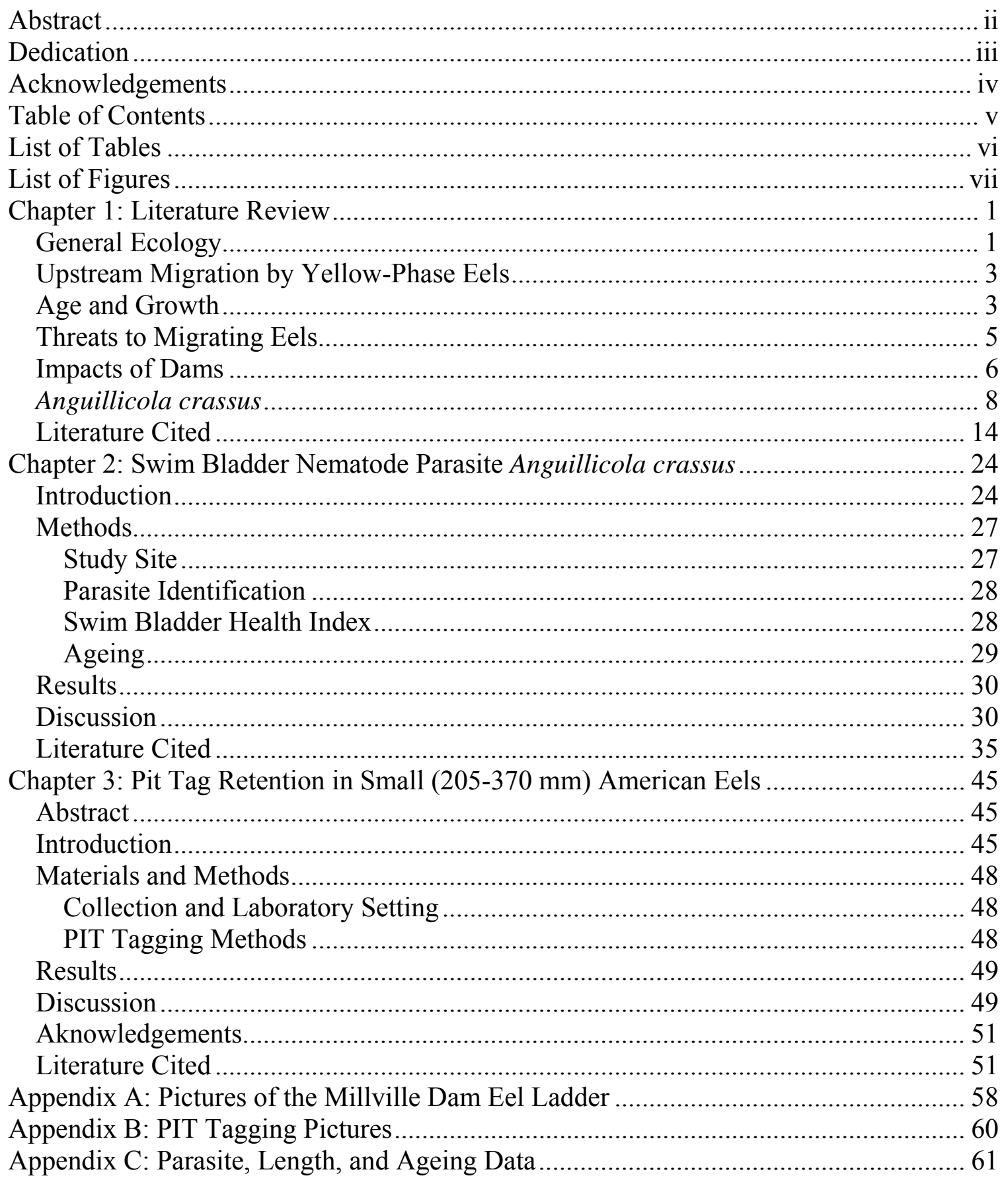




\section{List of Tables}

Table 2-1: Summary of prevalence and intensity of American eels collected from the Millville eel ladder on the Shenandoah River, WV.

Table 2-2: Summary of ages and lengths of a subsample of 42 American eels from the Shenandoah River. Of the 42 eels, 15 were those that either contained parasites in their swim bladder or eels that showed signs of a previous infection................................ 41

Table 3-1: Synthesis of PIT tag retention rates from American eel studies................... 56

Table 3-2: PIT tag retention in small American eels (205 - $370 \mathrm{~mm}$ total length) during a 9 week laboratory study $(\mathrm{P}=$ tag present, $\mathrm{H}=$ head tag shed, $\mathrm{D}=$ dorsal tag shed, and $\mathrm{A}=$ abdominal tag shed). 56 


\section{List of Figures}

Figure 2-1: Location of the eel ladder at Millville Dam on the Shenandoah River, WV..42

Figure 2-2: Frequency distribution of the swim bladder degenerative index (SDI). The SDI was used to determine the impact of $A$. crassus on the swim bladder of upstream migrant American eels captured at the Millville eel ladder on the Shenandoah River. A value of 0 corresponds to a healthy intact swim bladder, 1 to 3 is a moderately damaged

swim bladder, and 4 to 6 is a severely damaged swim bladder.

Figure 2-3: Frequency distribution of the swim bladder degenerative index criteria including the transparency of the swim bladder, the presence of pigmentation and exudates, and the thickness of the swim bladder. The SDI was used to determine the impact of $A$. crassus on the swim bladder of upstream migrant American eels captured at the Millville eel ladder on the Shenandoah River. Scores ranged from 0 to 6, with a 0 indicating no pathological signs of infection were observed and 6 denoting extreme

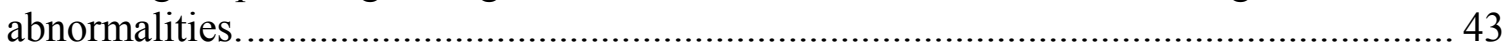

Figure 2-4: Age to Swim bladder degenerative index score relationships of American eels

from the Millville Dam eel ladder, Shenandoah River, WV. 44

Figure 3-1: PIT tag location for American eels including 1) dorsal musculature behind the head, 2) dorsal musculature near the dorsal fin origin, and 3) the abdominal cavity...... 57 


\section{Chapter 1: Literature Review}

This thesis includes three chapters. The first chapter is a review of American eel ecology, and consists of information on general ecology, upstream migration, age and growth patterns, dams and eel ladders, and the parasite Anguillicola crassus. The second chapter is on the swim bladder nematode parasite A. crassus in American eels utilizing the eel ladder on the Shenandoah River, WV, and includes a swim bladder health index and an ageing component. The final chapter is a laboratory study on PIT tag retention in small American eels.

\section{General Ecology}

The American eel, Anguilla rostrata, ranges from Greenland to Venezuela and colonizes a wide variety of habitat types, including lakes, streams, and estuaries (Facey and Van den Avyle 1987). In the United States, American eels are found in Atlantic coastal drainages, and the Mississippi watershed as far inland as Minnesota (Facey and Van den Avyle 1987; Tesch 2003). The range of the American eel has been documented as $5^{\circ}$ to $60^{\circ} \mathrm{N}$ (Bertin 1956), and covers approximately $30,000 \mathrm{~km}$ of coastline (50 CFR 17). This widely-distributed species is thought to inhabit the broadest array of habitats of any fish in the world (Helfman et al. 1987).

American eels were once an important food source to Native Americans and early European settlers due to their high nutritional value (Casselman 2003). Today, American eels still represent a valuable resource and support a large commercial fishery on the Atlantic coast (ASMFC 2007). Landings of yellow and silver eels totaled 738,657 pounds in 2006, with New Jersey, Delaware, and Maryland accounting for $69 \%$ of the catch (ASMFC 2007). Additionally, eels are commonly used as bait for larger game fish, like the striped bass (ASMFC 2007). American eels are also preyed upon by a variety of fishes, mammals and birds, including striped bass, mink, raccoon, and bald eagles (Sinha and Jones 1967; Seymour 1974; Thompson et al. 2005). As they can contribute up to 
$25 \%$ of the biomass in individual systems, they may be a very important part of the food web (Smith and Sauders 1955; Ogden 1970). However, their importance to other species is not well documented in the literature (ASMFC 2000).

The life cycle of the American eel is considered to be facultative catadromous. Eels spawn in the marine waters of the Sargasso Sea, and after an oceanic larval period, migrate into estuaries and rivers where they feed and mature (ASMFC 2000). The term "facultative" is used because some eels may remain in saltwater until the onset of their downstream spawning migration without ever entering freshwater (Morrison et al. 2003; Lamson et al. 2006). Migrations between saltwater and freshwater have also been documented (Jessop et al. 2002). Upon reaching maturity, eels migrate downstream to the Sargasso Sea, where they spawn and die (Facey and Van den Avyle 1987). Scientists propose that spawning occurs on the warm side of thermal fronts during the winter and spring (McCleave and Kleckner 1985; McCleave et al. 1987), however, no direct spawning of American eels has been observed, and spawning locations have only been inferred by the collection of larvae (Kleckner et al. 1983; Kleckner and McCleave 1985).

American eels undergo several phases throughout their life cycle. The first life stage is the larval eel, termed leptocephali. Leptocephali passively drift in the upper $250 \mathrm{~m}$ of Sargasso Sea for about a year and metamorphose into glass eels over the continental shelf (Castonguay and McCleave 1987). Glass eels use selective tidal transport to begin migration into estuaries, where they become pigmented and enter the elver life stage (McCleave and Wippelhauser 1987). Elvers stall at the freshwater saltwater interface before continuing to migrate upstream (Sorensen and Bianchini 1986).

The next phase is the yellow eel, which may last from 7 to 30 years. This life stage, characterized by a lack of sexual maturity, includes growth and maturation (Helfman et al. 1987). Yellow eels either remain in saltwater systems or migrate upstream into freshwater where they feed and grow to maturity before migrating downstream (Morrison et al. 2003; Lamson et al. 2006). During or before downstream migration, eels become sexually mature adults, or silver eels, and undergo a number of physiological changes to 
equip themselves for the oceanic portion of their migration (reviewed in Facey and Van den Avyle 1987). Silver eels are thought to be semelparous; spawning once in the Sargasso Sea before dying (ASMFC 2000).

\section{Upstream Migration by Yellow-Phase Eels}

Upstream migrations of yellow eels in freshwater occur in the spring and fall from March to October (Richkus and Whalen 1999). Movements are thought to occur primarily at night, although migration may occasionally occur during the day (McGrath et al. 2003; Verdon et al. 2003). Verdon et al (2003) found that American eels were most active at 21:00 hours, peaked at 1:00 hours, and declined at dawn on the Richelieu River, Quebec Canada. Similarly, McGrath et al. (2003) reported American eel activity primarily between 19:30 and 5:30 hours at an eel ladder on the St. Lawrence River, New York.

Environmental influences on yellow eel upstream migration include temperature, river flow, rain events, and lunar cycle (Winn et al. 1975; Cairns and Hooley 2003; Hildebrand 2005). Hildebrand (2005) concluded that peaks in eels using an eel ladder at Millville Dam on the Shenandoah River, West Virginia coincided with low light lunar phases. Additionally, migrations were also associated with increased river flow (Hildebrand 2005). However, Cairns and Hooley (2003) found that although American eel catches decreased sharply in Prince Edward Island bays and estuaries during the full moon, lunar cycles were not a trigger for migration. Verdon et al. (2003) also found no correlation between eel catches and temperature, river flow, or lunar cycle despite the fact that most peaks in migration occurred with increased temperature.

\section{Age and Growth}

Growth rates of eels vary depending on latitude, with eels reaching larger sizes in the northern portion of their range than in the south (Helfman et al. 1987). Eels in the north also remain in freshwater systems for longer periods of time before migrating back to the Sargasso Sea (Helfman et al. 1987). Eels migrate from the north at 12 to 23 years of age, 
while eels migrate from the south at 6 to 7 years of age (Gray and Andrews 1971; Hansen and Eversole 1984). Males mature and migrate out of freshwater systems at younger ages than females, while females favor a long, slow growth that results in increased size and fecundity (Helfman et al. 1987).

In Georgia, Helfman et al. (1984) found that eels in freshwater were larger and older than estuarine eels, with lengths ranging from 344 to $486 \mathrm{~mm}$ and an average age of 6.2 years. In the estuaries, eels were on average 4.6 years old (Helfman et al. 1984). Hansen and Eversole (1984) found that in the brackish portion of the Cooper River, South Carolina, lengths of American eels ranged from $260 \mathrm{~mm}$ to $687 \mathrm{~mm}$, with the majority of eels ranging from 300 to $640 \mathrm{~mm}$ long. Ages ranged from 1 to 12 years, with a mean of 4.3 years. Most of the eels were older than 2 and younger than 7, suggesting that eels in this habitat migrate after ages 6 to 7. Michener and Eversole (1983) found similar results for eels from the Charleston Harbor, South Carolina. Eels in their study were an average of 4.4 years old and ranged from 213 to $719 \mathrm{~mm}$ in length. Females were also found to be larger than males in each age class and the youngest eels were found in saline waters (Michener and Eversole 1983).

Rulifson et al. (2004) documented the ages of American eels in Lake Mattamuskeet, adjacent creeks and canals, and in northwestern Pamlico Sound, North Carolina. They found that eels ranged from $280 \mathrm{~mm}$ to $580 \mathrm{~mm}$ TL and had an average age of 4.8 years. Eels located in the lake were larger and older than eels from the sound and canal areas (Rulifson et al. 2004). In the Chesapeake Bay, the majority of American eels ranged from 110 to $560 \mathrm{~mm}$ in size and most were ages 2 to 6 (Owens and Geer 2003). The age range in their study was 1 to 18 (Owens and Geer 2003).

Morrison and Secor (2003) reported that American eels in brackish water portions of the Hudson River were approximately 8 years old, while eels in freshwater portions were approximately 17 years old. In New Jersey streams, eels ranged from 3 to 19 years, and were on average 10 years old (Ogden 1970). American eels in the tidal creek system in Great Sippewisset Marsh, Massachusetts averaged 306 mm (Ford and Mercer 1986). 
Length for both brackish and freshwater eels was about $457 \mathrm{~mm}$. In the freshwater Lake Champlain, Vermont, American eels were an average of 15.9 years old and ranged from 430 to $900 \mathrm{~mm}$ in length (Facey and LaBar 1981). Gray and Andrews (1971) documented that American eels in brackish waters in Newfoundland migrated back to sea at ages 12 to 13 and were a mean size of $690 \mathrm{~mm}$.

Most of the studies on age and growth have taken place in estuaries, at the saltwater interface, or on tidally dominated coastal rivers. Few studies have focused on eels in inland waters (Goodwin and Angermeier 2003). Hildebrand (2005) found that eels in the Shenandoah River ranging from 214 to $550 \mathrm{~mm}$ TL were 3 to 10 years of age. This estimate is lower than other reported ages for American eels in the mid-latitude range (Goodwin and Angermeier 2003; Owens and Geer 2003). Goodwin and Angermeier (2003) also studied American eels in the Shenandoah River. They found that eels were a mean length of $767 \mathrm{~mm}$ and were on average 11 years of age, which is a higher estimate than most eels in the mid-latitude range and older than other age estimates for eels within the same watershed (Hildebrand 2005).

The differences in the age and size composition between the two studies may possibly be attributed to capture methods. Hildebrand (2005) captured upstream migrant eels using the Millville eel ladder, whereas Goodwin and Angermeier (2003) captured eels using boat electroshocking. Eels of Goodwin and Angermeier (2003) may have been larger

yellow eels with an established home range (Parker 1995; Hammond 2003), as Hammond (2003) found that large American eels (500-800 mm TL) in the Shenandoah River established home ranges during the summer.

\section{Threats to Migrating Eels}

Trends in capture data indicate that American eel population are declining (Castonguay et al. 1994 a,b; Richkus and Whalen 1999; Haro et al. 2000; Richkus and Whalen 2000; Casselman 2005). Casselman (2005) reported that during the 31-day peak migration period, the mean number of eels passing through the Moser Saunders Hydroelectric Dam 
at Cornwall, Ontario, decreased from over 27,000 eels to 274 eels per day in 2004 (Casselman 2005). Recruitment at the ladder had dwindled to $0.2 \%$ of its level since the early 1980s (COSEWIC 2006). Landings in the United States have also fallen from a high of 1.8 million pounds in 1985 to a low of 641,000 pounds in 2002 (ASMFC 2007).

Concern about the decline of eels has increased worldwide. Reports of diminished catches prompted the ASMFC to petition the American eel as an endangered or threatened species under the Endangered Species Act. NOAA Fisheries and U.S. Fish \& Wildlife Service underwent a 12-month status review to determine whether American eels should be protected under the Endangered Species Act (50 CFR 17). The findings of the status review indicated that listing the American eel as a threatened or endangered species was not warranted at this time. This decision was based on the elasticity of the eel's habitat use, their ability to live the duration of their lives in saltwater, their wide distribution, and the fact that their numbers still remain in the millions. Furthermore, there is still ample historic habitat available, recruitment trends appear to be stable, and the factors affecting eels do not threaten them at a population level (50 CFR 17 2007).

Factors implemented in the population decline of American eel include fishing pressure and habitat modification, including obstruction to migration, oceanic changes, and chemical contamination (Castonguay et al. 1994 a,b). Recently, the nematode parasite, Anguillacola crassus, has also been implemented as a potential threat to the eel population (Haro et al. 2000). Only a few studies have documented the presence of this nematode, and its spread throughout the Atlantic coastal watershed remains largely unknown (Barse and Secor 1999; Barse et al. 2001).

\section{Impacts of Dams}

Like many other fish species, American eels are affected by dams (Wiley et al. 2004; McCleave 2001; Haro and Castro-Santos 2000; Richkus and Whalen 2000). Impacts on downstream and upstream migrants include blockage of prime upstream habitat (McCleave 2001; Verdon et al. 2003; Verreault et al. 2004) and direct mortality by 
turbines to downstream migrants (McCleave 2001). Busch et al. (1998) used Geographic Information Systems (GIS) to assess the amount of available American eel habitat. They found that 15,115 dams on Atlantic coastal tributaries block upstream and downstream migration routes, and that these dams restricted $556,801 \mathrm{~km}$ to $90,755 \mathrm{~km}$ of American eel stream habitat; a total of $84 \%$ of all available habitat. The North Atlantic (Maine to Connecticut) had the greatest loss of habitat (91\%) with a reduction in stream access from $111,482 \mathrm{~km}$ to $10,349 \mathrm{~km}$. The Mid-Atlantic (New York through Virginia) had an $88 \%$ loss $(199,312 \mathrm{~km}$ to $24,534 \mathrm{~km})$ and the South Atlantic (North Carolina to Florida) had a $77 \%$ reduction in stream habitat $(246,007 \mathrm{~km}$ to $55,872 \mathrm{~km})$.

In the St. Lawrence watershed, Verreault et al. (2004) identified 151 hydrodams greater than 2.5 m equipped with turbines and 8,260 dams greater than $2.5 \mathrm{~m}$ without turbines. They estimate that these dams block $12,140 \mathrm{~km}^{2}$ of suitable eel habitat in the St, Lawrence watershed, and that this loss of habitat represents a loss of 836, 545 fecund females.

For yellow eels migrating upstream, barriers to migration may also significantly reduce recruitment into the upper watersheds, which may ultimately reduce the numbers of female eels migrating from upstream habitats to the Sargasso Sea (Verdon et al. 2003). Krueger and Oliveira (1999) suggest that phenotypic sex in American eels may be determined by environmental factors such as population density, and crowding is thought to produce males (Oliveira 1999; Oliveira et al. 2001). Reports of American eels congregating below barriers lacking fish passageways (Liew 1982; Wiley et al. 2004) could potentially result in imbalanced sex ratios dominated by males (Richkus and Whalen 1999; Haro et al. 2000). As American eels are a panmictic (randomly breeding) species, imbalanced sex ratios could impact the entire population. Other consequences of being detained below barriers include increased risk of predation, increased spread of disease, and increased competition for food (Haro et al. 2000).

As a mitigation measure, hydroelectric facilities and fishery management agencies have installed eel ladders on some hydropower dams to help pass American eels into the upper 
portions of watersheds. These passageways have proven an effective method to assist in the conservation of this species (Liew 1982; Laffaille et al. 2005). However, most river blockages do not contain any provisions for migrating fish, and those dams that do have fish passageways are not always evaluated for their effectiveness (Knights and White 1998; Verreault et al. 2004).

\section{Anguillicola crassus}

The swimbladder nematode parasite, Anguillicola crassus, is native to East Asia and is commonly found in the Japanese eel, Anguilla japonica (Moravec 1992), where it appears to do little harm (Nagawasa et al. 1994). The parasite is one of five helminthes found to infect eel swim bladders. The other species include A. globiceps from Eastern Asia, the South African species, A. papernai, the Australian parasite, A. australiensis, and A. novaezelandiae from New Zealand (Moravec and Taraschewski 1988). A. crassus is described as having a dark, plump, fusiform body that tapers on both ends and a rounded head end. Important taxonomic identifiers include a well sclerotized buccal cavity with an anterior rim that contains 22 large circumeral teeth (Moravec and Taraschewski 1988).

In the 1980's the parasite was accidentally introduced to the European eel, Anguilla anguilla, by an expanding eel commerce and has become widespread throughout most of Europe (Køie 1991). Since then, A. crassus has been documented in most European countries and in North Africa, where its dissemination closely resembles the full geographic range of the European eel (Lefebvre and Crivelli 2004). In some cases, the infection rate has been documented close to 100\% (Kennedy and Fitch 1990; Höglund and Thomas 1992; Nagasawa et al. 1994). In 1995, the first occurrence of A. crassus was identified in wild American eels in Winyah Bay, South Carolina (Fries et al. 1996) and has since been found in most of the states along the Atlantic seaboard, including Maine, Massachusetts, Rhode Island, Connecticut, New York, New Jersey, Delaware (John Clark, Delaware Department of Natural Resources and Environmental Control, personal communication), Maryland, Virginia, North Carolina, South Carolina, and Florida (Barse and Secor 1999; Barse et al. 2001; Moser et al. 2001; Geer 2003; Morrison and Secor 
2003; Rulifson et al. 2004; Sokolowski and Dove 2006; Machut and Limburg 2008; Aieta and Oliveira In Prep). Recently, the parasite has expanded into Canada and has been identified in New Brunswick and Nova Scotia (Aieta and Oliveira In Prep).

The life cycle of the parasite relies on predator/prey interactions (Kirk 2003) and can be completed in as little as two months at $20^{\circ} \mathrm{C}$ (De Charleroy et al. 1990). American eels become infected by the parasite when they consume an intermediate or paratenic host (De Charleroy et al. 1990; Thomas and Ollevier 1992). A paratenic host is a host species not required for completion of the parasite's life cycle; this host just passes the parasite to the definitive host (American eel). However, the obligate intermediate host is required for the completion of the parasite's development (Kirk 2003).

While no host species have been identified in North America, 37 species of marine, estuarine, and freshwater fish all serve as paratenic hosts in European eels (Höglund and Thomas 1992; Thomas and Ollevier 1992; Reimer et al. 1994; Kirk 2003). In addition, snails, amphibians, and insect larvae may also be potential paratenic hosts (Moravec 1996; Moravec and Škoríková 1998). Intermediate hosts have been identified in Europe as small crustaceans like ostracods and copepods (Thomas and Ollevier 1989; Moravec and Konecny 1994). No paratenic host species have been documented for Japanese eels (Nagawasa et al. 1994).

Once inside the eel's swim bladder, the parasite copulates and the eggs are expelled into water with the feces. Hatching into the $\mathrm{L}_{2}$ larvae occurs either during or after the passage through the eel's digestive tract. After entering the water, the $\mathrm{L}_{2}$ larvae attach to the substrate headfirst and undulate to stimulate predation by an intermediate host. Within the host, the larvae molt into the $\mathrm{L}_{3}$ infective stage, and eels consuming the intermediate host become infected (De Charleroy et al. 1990). Infection by an intermediate host can occur as early as the glass eel phase, as these eels are likely to feed on small crustaceans (Kennedy and Fitch 1990). 
The infected intermediate host can also be consumed by a paratenic host. In these host species, the $\mathrm{L}_{3}$ larvae remain alive, but do not complete their lifecycle until the eel consumes the paratenic host. Once in the eel's body, the $\mathrm{L}_{3}$ larvae pass through the intestinal wall and the body cavity to reach the swim bladder. After a couple of weeks, the parasite molts into the $\mathrm{L}_{4}$ stage where they consume blood and continue to grow. Molting occurs once more and the sexually mature adults begin reproduction (De Charleroy et al. 1990).

Few studies have documented the presence of A. crassus in American eels. In the Southeast, Moser et al. (2001) found high levels of infestation in North Carolina. They collected 1,111 eels from various rivers and estuaries and found that $52 \%$ of the eels were infected with the parasite. Prevalence rates ranged from $26 \%$ to $100 \%$ and mean intensity was 3.9 nematodes per eel (Moser et al. 2001). Rulifson et al. (2004) found that $35 \%$ of the eels in coastal lakes of Pamlico Sound, North Carolina were infected with the parasite, and that sexually undifferentiated eels had higher incidences of the parasite. Geer (2003) examined 126 eels in Virginia tributaries and found an infection rate of $61 \%$ in York River, a 44\% infection rate in the Rappahannock River and a 27\% infection rate in the James River.

Barse and Secor (1999) examined the swim bladders of 329 American eels in the Chesapeake Bay and 150 eels in the Hudson River, New York. They found that the prevalence was $10 \%$ to $29 \%$ in the Chesapeake Bay and $0 \%$ to $12 \%$ in the Hudson River. However, the authors state that these infection rates were an underestimate, as they only identified nematodes living in the swim bladder lumen, and did not count the juveniles stages of the parasite, which live in the swim bladder wall (Barse and Secor 1999).

Recent research in New York has shown increased infestations of the parasite as compared to earlier studies. Machut and Limburg (2008) found that prevalence averaged $39 \%$ in tributaries of the Hudson River and that eels contained an average intensity of 2.4 nematodes per eel. Sokolowski and Dove (2006) examined the pathology of American eels from the Carlls River, Babylon, New York, and found that 100\% of the eels showed 
evidence of previous or ongoing infections of the parasite. In the Northern United States, Aieta and Oliveira (In Prep) found that in Rhode Island the infection rate ranged from 28 to $69 \%$. In Massachusetts, prevalence ranged from 7 to $76 \%$, and in Maine, the percentage of eels infected by $A$. crassus was 0 to $65 \%$.

The parasite $A$. crassus exhibits many characteristics that makes it a successful invader (Kennedy and Fitch 1990; Kirk 2003; Kennedy 2007). It has a life cycle that can be completed in a short time period (De Charleroy et al. 1990), high reproductive potential (Kennedy and Fitch 1990), the ability to survive a wide range of environmental conditions in a host species (Kennedy and Fitch 1990; Kirk et al. 2000a,b), and it can occupy a vast array of host species (Kennedy and Fitch 1990; Kirk 2003). It also can infect eels of all sizes (Kennedy and Fitch 1990). Furthermore, the parasite has invaded an empty niche. Only one other nematode, Daniconema anguillae, is found in the eel's swim bladder, and unlike $A$. crassus, this parasite is usually found in the serous cover and only occurs in low numbers (Kirk 2003).

In Europe, the rapid dissemination of the parasite has been attributed to the introduction of eels into watersheds for stocking and human consumption, the natural movements of the eels, and regurgitation by piscivorous birds, like cormorants (Wlasow et al. 1998; Kirk 2003). Urbanization and introductions through ballast waters and bait buckets may also play a factor in the distribution of the parasite (Machut and Limburg 2008; Aieta and Oliveira In Prep). Recent research shows that urbanization may increase the eel's susceptibility to the parasite, and trends of elevated infection rates in urbanized areas have been found in eels from the Hudson River (Machut and Limburg 2008). Introductions via ballast water at commercial ports may further increase the distribution of the parasite (Aieta and Oliveira In Prep). Aieta and Oliveira (In Prep) found that in the northeast, prevalence and intensity were highest at sites located near major shipping ports.

The only limitations to the spread of $A$. crassus are thought to be host availability and temperature (Thomas and Ollevier 1993; Knopf et al. 1998; Kirk 2003). Knopf et al. 
(1998) found increased mortality, decreased growth, and decreased reproduction in adult worms held at $4{ }^{\circ} \mathrm{C}$ for four months. Therefore, the authors concluded that the parasite would be unable to colonize the most northerly parts of the American eel's range (Knopf et al. 1998). However, Aieta and Oliveira (In Prep) located the parasite as far north as Cape Breton Island, Nova Scotia, Canada, and documented well established parasite populations in eels in Penobscot River, Maine, where temperatures are often below $4{ }^{\circ} \mathrm{C}$ for four months a year. Thus, indicating that temperature may not halt the invasion of the parasite as suggested by other studies (Aieta and Oliveira In Prep).

Dams may also slow the spread of $A$. crassus by blocking the movement and distribution of host species (Machut and Limburg 2008). As many fish host species are unable to circumvent natural and manmade barriers, the spread of the parasite is dependent on American eel upstream migrations, and could take a long time to reach currently healthy systems (Machut and Limburg 2008). Once established within a particular watershed, eels exhibit home ranging behavior (Parker 1995), which may decrease the likelihood of spreading the parasite to other systems (Aieta and Oliveira In Prep).

Many studies have suggested that the nematode parasite may be detrimental to Anguilla eels and propose that the parasite could ultimately impact reproduction (Sprengel and Lüchtenberg 1991; Molnár 1994; Barse and Secor 1999; Palstra et al. 2007a). Mass mortality has been reported in the European eel (Molnár et al. 1991) and in American eels from eel farms in Taiwan (Ooi et al. 1996). Other documented effects include enlarged abdomens, swim bladder rupture, dilation of the blood vessels in the swim bladder, thickened swim bladder wall, skin ulcers in the abdomen, a red and swollen anus, increased stress response to hypoxia, damage to the gas glands, increase in spleen mass, and secondary bacterial infections (van Banning and Haenen 1990, Molnár et al. 1993; Molnár 1994; Würtz et al. 1996; Nimeth et al. 2000; Würtz and Taraschewski 2000; Crean et al. 2003; Lefebvre et al. 2004; Gollock et al. 2005; Sokolowski and Dove 2006).

The parasite may also impact the swimming ability of eels, which could impair the eel's ability to complete their migration and make them more susceptible to predation and 
capture in both fisheries and cooling water intakes (Sprengel and Lüchtenberg 1991; Kirk 2003; Kennedy 2007; Palstra et al. 2007a,b). A study by Sprengel and Lüchtenberg (1991) compared maximum swimming speeds of Europeans eels infected with A. crassus with uninfected eels in a laboratory setting. They demonstrated that the presence of $A$. crassus in European eels had an impact on swimming speed. Results of their study showed the presence of the nematode parasite in the swim bladder of the eel reduced swimming speeds in eels with more than 10 nematodes. Based on this, the authors speculate that eels infected with nematodes would be unlikely to reach the spawning grounds in the Sargasso Sea. Furthermore, they suggest that fish with a decreased ability to swim would not be as effective in competing for food and would be more likely to be affected by anthropogenic impacts (Sprengel and Lüchtenberg 1991).

More recently, Palstra et al. (2007a) found that infected silver European eels and silver eels with damaged swim bladders showed a reduced swimming performance, a loss of endurance, and were less efficient swimmers. Results of their swimming fitness tests found that silver eels had higher oxygen consumption, lower optimum swim speeds, and higher cost of transport at optimum swim speeds. They state that infected eels and eels with heavily damaged swim bladders would need to spend at least $20 \%$ more of their energy reserves on migration, leaving less fat for egg production. The reduced swimming performance could also cause an increase in the duration of the migration causing delays in reaching the spawning grounds. The authors conclude that the parasite is a serious threat to reproductive success in European eels and speculate that the parasite may have played a role in the collapse of the eel population. Palstra et al. (2007b) may also have observed migration failure in silver European eels. During laboratory migration simulations, six eels showed problems swimming and did not reach the 1000 $\mathrm{km}$ border, indicating an inability to migrate the distance needed to reach the Sargasso Sea. Half of these eels were infected with the swim bladder parasite and $83 \%$ of them had heavily damaged swim bladders, suggesting a decreased swimming performance due to the parasite. 
These finding contrast with Münderle et al. (2004), who found that the parasite did not affect the amount of the time the eels were able to withstand a current. Eels used by Palstra et al. (2007a), however, were much larger, in a different developmental stage, and exposed to swimming trials of a longer duration. One could assume that impacts of the swim bladder parasite are similar for European and American eels. Preferably, however, additional research should be conducted on the impacts of A. crassus to American eels.

\section{Literature Cited}

50 CFR 17. 2007. Endangered and threatened wildlife and plants; 12 month finding on a petition to list American eels as threatened or endangered. Department of the Interior, U.S. Fish and Wildlife Service. 72(22). 31 pages.

Aieta, A.E. and K. Oliveira. In Prep. The distribution, prevalence, and intensity of the swim bladder parasite Anguillicola crassus in New England and eastern Canada. Diseases of Aquatic Organisms.

Atlantic States Marine Fisheries Commission (ASMFC). 2000. Interstate Fishery Management Plan for American eel (Anguilla rostrata). Fisheries Management Report No. 36. Washington, DC.

Atlantic States Marine Fisheries Commission (ASMFC). 2007. Review of the Atlantic States Marine Fisheries Commission fishery management plan for American eel (Anguilla rostrata).

Barse, A.M. and D.H. Secor. 1999. An exotic nematode parasite of the American eel. Fisheries 24: 6-10.

Barse, A.M., S.A. McGuire, M.A. Vinores, L.E. Eierman, and J.A. Weeder. 2001. The swim bladder nematode Anguillicola crassus in American eels (Anguilla rostrata) from middle and upper regions of the Chesapeake Bay. Journal of Parasitology 87(6): 1366-1370.

Bertin, L. 1956. Eels: A biological study. Cleaver-Hume Press, Ltd., London. 197 pages.

Busch, W.-D.N., S.J. Lary, C.M. Castiglione and R. McDonald. 1998. Distribution and availability of Atlantic coast freshwater habitats for American eel (Anguilla rostrata). Administrative Report \#98-2. USFWS, Amherst, NY. 28pp.

Cairns, D.K. and P.J.D. Hooley. 2003. Lunar cycles of American eels in tidal waters of 
the southern Gulf of St. Lawrence, Canada. American Fisheries Society Symposium 33: 265-274.

Casselman, J.M. 2003. Dynamics of resources of the American eel, Anguilla rostrata: declining abundance in the 1990's. Pages 255-274 in K. Aida, K. Tsukamoto, K. Yamauchi, editors. Eel Biology. Springer-Verlag, Toyoko.

Casselman, J.M. 2005. American eel dynamics and abundance: a fish resource in unprecedented decline. J.M. Casselman and D. Cairns (eds.) International Eel Symposium, American Fisheries Society Special Publication. In review.

Castonguay, M. and J.D. McCleave. 1987. Vertical distributions, diel and otogenetic vertical migrations and net avoidance of leptacephali of Anguilla and other common species in the Sargasso Sea. Journal of Plankton Research 9: 195-214.

Castonguay, M., P.V. Hodson, C.M. Couillard, M.J. Eckersley, J.-D. Dutil and G. Verreault. 1994a. Why is recruitment of the American eel, Anguilla rostrata, declining in the St. Lawrence River and Gulf? Canadian Journal of Fisheries and Aquatic Science 51: 479-488.

Castonguay, M., P.V. Hodson, C. Moriarty, K.F. Drinkwater, and B.M. Jessop. 1994b. Is there a role in the ocean environment in American and European eel decline? Fisheries Oceanography 3(3): 197-203.

COSEWIC 2006. COSEWIC assessment and status report on the American eel Anguilla rostrata in Canada. Committee on the Status of Endangered Wildlife in Canada. Ottawa. $x+71$ pp. (www.sararegistry.gc.ca/status/status_e.cfm).

Crean, S.R., J.T.A. Dick, D.W. Evans, R.W. Elwood, and R.S. Rosell. 2003. Anal redness in European eels as an indicator of infection by the swimbladder nematode Anguillicola crassus. Journal of Fish Biology 62: 482-485.

De Charleroy, D., L. Grisez, K. Thomas, C. Belpaire, and F. Ollevier. 1990. The life cycle of Anguillicola crassus. Diseases of Aquatic Organisms 8: 77-84.

Facey, D.E. and G.W. LaBar. 1981. Biology of American eels in Lake Champlain, Vermont. Transactions of the American Fisheries Society 110: 396-402.

Facey, D.E. and M.J. Van den Avyle. 1987. Species profiles: Life histories and environmental requirements of coastal fishes and invertebrates (North Atlantic) American eel. U.S. Fish and Wildlife Service Biological Report 82(11.74). U.S. Army Corps of Engineers, TR EL-82-4. 28 pp.

Ford, T.E. and E. Mercer. 1986. Density size distribution and home range of American eels, Anguilla rostrata, in a Massachusetts salt marsh. Environmental Biology of Fishes 17: 309-314. 
Fries, L.T., D.J. Williams, and S.K. Johnson. 1996. Occurrence of Anguillicola crassus, an exotic parasitic swim bladder nematode of eels, in southeastern United States. Transactions of the American Fisheries Society 125: 794-797.

Geer, P.J. 2003. Distribution, relative abundance, and habitat use of American eel Anguilla rostrata in the Virginia portion of the Chesapeake Bay. American Fisheries Society Symposium 33: 101-115.

Gollock, M.J., C.R. Kennedy, and J.A. Brown. 2005. European eels, Anguilla anguilla (L.), infected with Anguillicola crassus exhibit a more pronounced stress response to severe hypoxia than uninfected eels. Journal of Fish Diseases 28: 429-436.

Goodwin, K.R. and P.L. Angermeier. 2003. Demographic characteristics of American eel in the Potomac River drainage, Virginia. Transactions of the American Fisheries Society 132: 525-535.

Gray, R.W. and C.W. Andrews. 1971. Age and growth of American eel (Anguilla rostrata (LeSueur)) in Newfoundland waters. Canadian Journal of Zoology 49: 121-128.

Hammond, S. 2003. Seasonal movements of yellow-phase American eels (Anguilla rostrata) in the Shenandoah River, West Virginia. Master's Thesis, West Virginia University, Morgantown, WV.

Hansen, R.A. and A.G. Eversole. 1984. Age, growth, and sex ratios of American eels in brackish-water portions of a South Carolina river. Transactions of the American Fisheries Society 113: 744-749.

Haro, A. and T. Castro-Santos. 2000. Behavior and passage of the silver-phase American eels, Anguilla rostrata (LeSueur) at a small hydroelectric facility. Dana 12: 33-42.

Haro, A., W. Richkus, K. Whalen, A. Hoar., W.-D, Busch, S. Lary, T. Brush, and D. Dixon. 2000. Population decline of the American eel: Implications for research and management. Fisheries 25(9): 7-16.

Helfman, G.S., E.L. Bozeman, and E.B. Brothers. 1984. Size, age, and sex of American eels in a Georgia river. Transactions of the American Fisheries Society 115: 132141.

Helfman, G.S., D.E. Facey, L.S. Hales Jr., and E.L. Bozeman Jr. 1987. Reproductive ecology of the American eel. American Fisheries Society Symposium 1: 42-56.

Hildebrand, H. 2005. Size, age composition, and upstream migration of American eels 
at Millville Dam eel ladder, Shenandoah River, West Virginia. Master's Thesis, West Virginia University, Morgantown, WV.

Höglund, J. and K. Thomas. 1992. The black goby Gobius niger as a potential paratenic host for the parasitic nematode Anguillicola crassus at a thermal effluent of the Baltic. Diseases of Aquatic Organisms 12: 175-180.

Jessop, B.M., J.-C. Shiao, Y. IiZuka, W.-N. Tzeng. 2002. Migratory behavior and habitat use by American eels Anguilla rostrata as revealed by otolith microchemistry. Marine Ecology Progress Series 233: 217-229.

Kennedy, C.R. 2007. The pathogenic helminth parasites of eels. Journal of Fish Diseases 30: 319-334.

Kennedy, C.R. and D.J. Fitch. 1990. Colonization, larval survival and epidermiology of the nematode, Anguillicola crassus, in Britain. Journal of Fish Biology 36: 117131.

Kirk, R.S. 2003. The impact of Anguillicola crassus on European eels. Fisheries Management and Ecology 10: 385-394.

Kirk, R.S., C.R. Kennedy, and J.W. Lewis. 2000a. Survival and transmission of Anguillicola crassus Kuwahara, Niimi \& Itagaki, 1974 (Nematoda) in seawater eels. Parasitology 120: 289-295.

Kirk, R.S., C.R. Kennedy, and J.W. Lewis. 2000b. Effect of salinity on hatching, survival and infectivity of Anguillicola crassus (Nematoda: Dracunculoidae) larvae. Diseases of Aquatic Organisms 40: 211-218.

Kleckner, R.C. and J.D. McCleave. 1985. Spatial and temporal distribution of American eel larvae in relation to North Atlantic Ocean current systems. Dana 4: 67-92.

Kleckner, R.C., J.D. McCleave, and G.S. Wippelhauser. 1983. Spawning of American eel, Anguilla rostrata, relative to thermal fronts in the Sargasso Sea. Environmental Biology of Fishes 9: 289-293.

Knopf, K., J. Würtz, B. Sures, and H. Taraschewski. 1998. Impact of low water temperature on the development of Anguillicola crassus in the final host Anguilla anguilla. Diseases of Aquatic Organisms 33: 143-149.

Køie, M. 1991. Swim bladder nematodes (Anguillicola spp.) and gill monogeneans (Pseudodactylogyrus spp.) parasitic on the European eel (Anguilla anguilla). Journal du Conseil - Conseil international pour l'Exploration de la Mer 47: 391398.

Knights, B. and E.M. White. 1998. Enhancing immigration and recruitment of eels: The 
use of passes and associated trapping systems. Fisheries Management and Ecology 5: 459-471.

Krueger, W. and K. Oliveira. 1999. Evidence for environmental sex determination in the American eel, Anguilla rostrata. Environmental Biology of Fishes 55: 381-389.

Laffaille, P., A. Acou, J. Guillouët, and A. Legault. 2005. Temporal changes in European eel, Anguilla anguilla, stocks in a small cachment after installation of a fish pass. Fisheries Management 12: 123-129.

Lamson, H.M., J.-C. Shiao, Y. Lizuka, W.-N. Tzeng and D.H. Cairns. 2006. Movement patterns of American eels (Anguilla rostrata) between salt and fresh water in a coastal watershed, based on otolith microchemistry. Marine Biology 149: 1567-1576.

Lefebvre, F.S., and A.J. Crivelli. 2004. Anguillicolosis: dynamics of the infection over two decades. Diseases of Aquatic Organisms 62: 227-232.

Lefebvre, F.S., B. Mounaix, G. Puizat, and A.J. Crivelli. 2004. Impacts of the swimbladder nematode Anguillicola crassus on Anguilla anguilla: variations in liver and spleen mass. Journal of Fish Biology 64: 435-447.

Liew, P.H.L. 1982. Impact of the eel ladder on the upstream migrating eel (Anguilla rostrata) population in the St. Lawrence River at Cornwall. Pages 1974-1978. In K.H. Loftus (ed.), Proceedings of the 1980 North American Eel Conference. Ontario Fisheries Technical Report Series No. 4, pp 17-22.

Machut, L.S. and K.E. Limburg. 2008. Anguillicola crassus infection in Anguilla rostrata from small tributaries of the Hudson River watershed, New York, USA. Diseases of Aquatic Organisms 79: 37-45.

McCleave, J.D. 2001. Simulation of the impact of dams and fishing weirs on reproductive potential of silver-phase American eels in the Kennebec River basin, Maine. North American Journal of Fisheries Management 21: 592-605.

McCleave, J.D. and R.C. Kleckner. 1985. Oceanic migrations of Atlantic eels (Anguilla spp.): Adults and their offspring. Contributions in Marine Science 27: 316-337.

McCleave, J.D. and G.S. Wippelhauser. 1987. Behavioral aspects of selective tidal stream transport in juvenile American eels. American Fisheries Society Symposium 1:138-150.

McCleave, J.D., R.C. Kleckner, and M. Castonguay. 1987. Reproductive sympatry of American and European eel and implications for migration and taxonomy. American Fisheries Society Symposium 1: 268-297. 
McGrath, K.J., D. Desrochers, C. Fleury, and J.W. Dembeck IV. 2003. Studies of upstream migrant American eels at the Moses-Saunders power dam on the St. Lawrence River near Massena, New York. American Fisheries Society Symposium 33: 153-166.

Michener, W.K. and A.G. Eversole. 1983. Age, growth, and sex ratios of American eels in Charleston Harbor, South Carolina. Proceedings of the Annual Conference of the Southeast Association of Fish and Wildlife Agencies 37: 422-431.

Molnár, K. 1994. Formation of parasitic nodules in the swim bladder and intestinal walls of the eel, Anguilla anguilla due to infections with larval stages of Anguillicola crassus. Diseases of Aquatic Organisms 20: 163-170.

Molnár, K., C.S. Székely, and F. Baska. 1991. Mass mortality of eels in Lake Balaton due to Anguillicola crassus infection. Bulletin of the European Association of Fish Pathologists 11: 211-212.

Molnár, K., F. Baska, G.Y. Csaba, R. Glávits, and C.S. Székely. 1993. Pathological and histopathological studies of the swim bladder of eels Anguilla anguilla infected by Anguillicola crassus (Nematoda: Dracunculoidea). Diseases of Aquatic Organisms 15: 41-50.

Moravec, F. 1992. Spreading of the nematode Anguillicola crassus (Dracunculoidea) among eel populations in Europe. Folia Parasitologica 39: 247-248.

Moravec, F. 1996 Aquatic invertebrates (snails) as new paratenic hosts of Anguillicola crassus (Nematoda: Dracunculoidea) and the role of paratenic hosts in the life cycle of the parasite. Diseases of Aquatic Organisms 27: 237-239.

Moravec, F. and H. Taraschewski. 1988. Revision of the genus Anguillicola Yamaguti, 1935 (nematoda: Anguillicolidae) of the swimbladder of eels, including descriptions of two new species, A. novaezelandiae SP. N. and A. papernai SP. N. Folia Parasitologica 35: 125-146.

Moravec, F. and R. Konecny. 1994. Some new data on the intermediate and paratenic hosts of the nematode Anguillicola crassus Kuwahara, Niimi et Itagaki 1974 (Dracunculoidea), a swim bladder parasite in eels. Folia Parasitologica 41: 65-70.

Moravec, F. and B. Škoríková. 1998. Amphibians and larvae of aquatic organisms as new paratenic hosts of Anguillicola crassus (Nematoda: Dracunculoidea), a swim bladder parasite of eels. Diseases of Aquatic Organisms 34: 217-222.

Morrison, W.E. and D.H. Secor. 2003. Demographic attributes of yellow-phase American eels (Anguilla rostrata) in the Hudson River estuary. Canadian Journal of Fisheries and Aquatic Sciences 60:1487-1501. 
Morrison, W.E., D.H. Secor, P.M. Piccoli. 2003. Estuarine habitat use by Hudson River American eels as determined by otolith strontium: calcium ratios. American Fisheries Society Symposium 33: 87-99.

Moser, M.L., W.S. Patrick, and J.U. Crutchfield, Jr. 2001. Infection of American eels, Anguilla rostrata, by and introduced nematode parasite, Anguillicola crassus, in North Carolina. Copia 3: 848-853.

Münderle, M., B. Sures, and H. Taraschewski. 2004. Influence of Anguillicola crassus (Nematoda) and Ichthyophthirius multifilis (Ciliophora) on swimming activity of European eel Anguilla anguilla. Diseases of Aquatic Organisms 60: 133-139.

Nagasawa, K., Y-G. Kim, and H. Hirose. 1994. Anguillicola crassus and A. globiceps (Nematoda: Dracunculoidea) parasitic in the swim bladder of eels (Anguilla japonica and A. anguilla) in East Asia: A review. Folia Parasitologica 41: 127137.

Nimeth, K., P. Zwerger, J. Würtz, W. Salvenmoser, and B. Pelster. 2000. Infection of the glass-eel swimbladder with the nematode Anguillicola crassus. Parasitology 121: $75-83$.

Ogden, J.C. 1970. Relative abundance, food habits, and age of the American eel, Anguilla rostrata (LeSueur), in certain New Jersey streams. Transactions of the American Fisheries Society. 99(1): 54-59.

Oliveira, K. 1999. Life history characteristics and strategies of American eel, Anguilla rostrata. Canadian Journal of Fisheries and Aquatic Science 56: 795-802.

Oliveira, K., J.D. McCleave, and G.S. Wippelhauser. 2001. Regional variation and the effect of lake : river area on sex distribution of American eels. Journal of Fish Biology 58: 943-952.

Ooi, H.-K., W.-S. Wang, H.-Y. Chang, C.-H. Wu, C.-C. Lin, and M.-T. Hsieh. 1996. An epizootic of anguillicolosis in cultured American eels in Taiwan. Journal of Aquatic Animal Health 8: 163-166.

Owens, S.J. and P.J. Geer. 2003. Size and age of American eels collected from tributaries of the Virginia portion of the Chesapeake Bay. American Fisheries Society Symposium, 33: 117-124.

Palstra, A.P., D.F.M. Heppener, V.J.T. van Ginneken, C. Székely, and G.E.E.J.M. van den Thillart. 2007a. Swimming performance of silver eels is severely impaired by the swim-bladder parasite Anguillicola crassus. Journal of Experimental Marine Biology and Ecology 352: 244-256.

Palstra, A., D. Curiel, M. Fekkes, M. de Bakker, C. Székely, V.J.T. van Ginneken, and 
G.E.E.J.M. van den Thillart. 2007b. Swimming stimulates oocyte development in European eel. Aquaculture 270: 321-332.

Parker, S.J. 1995. Homing ability and home range of yellow-phase American eels in a tidally dominated estuary. Journal of the Marine Biological Association of the United Kingdom 75: 127-140.

Reimer, L.W., A. Hildebrand, D. Scharberth, and U. Walter. 1994. Anguillicola crassus in the Baltic Sea: field data supporting transmission in brackish waters. Diseases of Aquatic Organisms 18: 77-79.

Richkus, W.A. and K.G. Whalen. 1999. American eel (Anguilla rostrata) scoping study report. Final Report, March, 1999 by Versar, Inc., prepared for Electric Power Research Institute.

Richkus, W.A. and K.G. Whalen. 2000. Evidence for a decline in the abundance of the American eel, Anguilla rostrata (LeSueur), in North America since the early 1980's. Dana 12: 83-97.

Rulifson, R.A., C. Cahoon, and J.L. Cudney. 2004. Critical habitat assessment and population demographics of the American eel fishery in Northwestern Pamlico Sound, North Carolina. Final Report, Fishery Resource Grant Program, Project 02-EP-13.

Seymour, N.R. 1974. Great black-backed gulls feeding on live eel. Canadian Field Naturalist 8: 352-353.

Sinha, V.R.P. and J.W. Jones. 1967. On the food of the freshwater eel and their feeding relationship with salmonids. Journal of Zoology (London) 153: 119-137.

Smith, M.W. and J.W. Saunders. 1955. The American eel in certain freshwaters of the Maritime Provinces of Canada. Journal of the Fisheries Research Board of Canada 12: 238-269.

Sokolowski, M.S. and A.D.M. Dove. 2006. Histopathological examination of wild American eels infected with Anguillicola crassus. Journal of Aquatic Animal Health 18: 257-262.

Sorensen, P.W. and M.L. Bianchini. 1986. Environmental correlates of the freshwater migration of elvers of the American eel in a Rhode Island brook. Transactions of the American Fisheries Society 115: 258-268.

Sprengel, G. and H. Lüchtenberg. 1991. Infection by endoparasites reduces maximum swimming speed of European smelt Osmerus eperlanus and European eel Anguilla anguilla. Diseases of Aquatic Organisms 11: 31-35. 
Tesch, F.-W. 2003. The Eel. Translated from German by R. J. White, Edited by J. E. Thorpe. Blackwell Science Ltd., U.K.. 408 p.

Thomas, K. and F. Ollevier. 1992. Paratenic hosts of the swimbladder nematode Anguillicola crassus. Diseases of Aquatic Organisms 13: 165-174.

Thomas, K. and F. Ollevier. 1993. Hatching, survival and penetration efficiency of second-stage larvae of Anguillicola crassus (Nematoda). Parasitology 107: 211217.

Thompson, C.M., P.E. Nye, G.A. Schmidt, and D.K. Garcelon. 2005. Ecology of bald eagles in a freshwater tidal system. Journal of Wildlife Management 69(2): 609617.

van Banning, P. and O.L.M. Haenen. 1990. Effects of the swim bladder nematode Anguillicola crassus in wild and farmed eel, anguilla anguilla. Pages 317-330 in F.O. Perkins and T.C. Cheng (eds.). Pathology in Marine Science. Proceedings of the Third International Colloquium on Pathology in Marine Aquaculture held in Gloucester Point, Virginia, 2-6 October 1998. Academic Press, Inc., San Diego, CA.

Verdon, R., D. Desrochers, P. Dumont. 2003. Recruitment of American eels in the Richelieu River and Lake Champlain: Provision of upstream passage as a regional-scale solution to a large-scale problem. American Fisheries Society Symposium 33: 125-138.

Verreault, G., P. Dumont, and Y. Mailhot. 2004. Habitat losses and anthropogenic barriers as a cause of population decline for American eel (Anguilla rostrata) in the St. Lawrence watershed, Canada. ICES CM 2004/S:04.

Wlasow, T., P. Gomulka, A. Martyniak, S. Boron, P. Hliwa, J. Terlecki, and U. Szymanska. 1998. Anguillicola crassus larvae in cormorant's prey fish in Vistula Lagoon, Poland. Bulletin Français de la Pêche et de Pisciculture 349: 223-227.

Wiley, D.J., R.P. Morgan II, R.H. Hilderbrand, R.L. Raesly, and D.L. Shumway. 2004. Relations between physical habitat and American eel abundance in five river basins in Maryland. Transactions of the American Fisheries Society 133: 515526.

Winn, H.E., W.A. Richkus, and L.K. Winn. 1975. Sexual dimorphism and natural movements of the American eel (Anguilla rostrata) in Rhode Island streams and estuaries. Helgoländer wiss. Meeresunters 27: 156-166.

Würtz, J. and H. Taraschewski. 2000. Histopathological changes in the swimbladder wall of the European eel Anguilla anguilla due to infections with Anguillicola crassus. Diseases of Aquatic Organisms 39: 121-134. 
Würtz, J., H. Taraschewski, and B. Pelster. 1996. Changes in the gas composition of the swimbladder of the European eel (Anguilla anguilla) infected with Anguillicola crassus (Nematoda). Parasitology 112: 233-238. 


\section{Chapter 2: Swim Bladder Nematode Parasite Anguillicola crassus}

\section{Introduction}

The American eel, Anguilla rostrata, is a commercially important fish species along the east coast of the United States, particularly in the mid-Atlantic region (ASMFC 2007). Data from commercial fish landings, upstream passage counts, and seine, trawl, and electrofishing surveys indicate that American eel populations are in decline throughout their range (Haro et al. 2000; Casselman 2003). As a result, concern about eel species has increased worldwide (ASMFC 2007, Haro et al. 2000, Cassleman 2005, COSEWIC 2006). Habitat modification, fishing pressure, pollution, and oceanic changes have all been cited as potentially playing a role in the decline of the American eel (Castonguay et al. $1994 \mathrm{a}, \mathrm{b})$. In addition, the recently identified invasive swim bladder nematode parasite, Anguillicola crassus, has also been implemented as another possible contributing factor to the decline (Haro et al. 2000).

The nematode, A. crassus, is native to Asia and is commonly found in Japanese eels, where it appears to cause little harm (Nagawasa et al. 1994). The parasite's short life cycle, coupled with its high fecundity, ability to tolerate a wide range of salinities, and use multiple paratenic hosts to complete its lifecycle, makes it a highly successful invasive colonizer (Kennedy and Fitch 1990; Kirk 2003; Kennedy 2007). It was introduced to Europe via eel commerce in the early 1980's and has since spread rapidly throughout the continent. In many European watersheds, infestation levels are close to 100\% (Kennedy and Fitch 1990; Höglund and Thomas 1992; Nagasawa et al. 1994). To

date, it has been found in every European country and in North Africa (Lefebvre and Crivelli 2004).

The first documented case of A. crassus in the United States occurred the mid-1990s in a Texas aquaculture facility and in wild eels in Winyah Bay, South Carolina (Fries 1996). Since then, it has been detected in almost all of the states along the Atlantic seaboard, 
including Maine, Massachusetts, Rhode Island, Connecticut, New York, New Jersey, Delaware (John Clark, Delaware Department of Natural Resources and Environmental Control, personal communication), Maryland, Virginia, North Carolina, South Carolina, and Florida (Barse and Secor 1999; Barse et al. 2001; Moser et al. 2001; Geer 2003; Morrison and Secor 2003; Rulifson et al. 2004; Sokolowski and Dove 2006; Machut and Limburg 2008; Aieta and Oliveira In Prep). Reported infection rates in the United States range from 0 to 100\% (Sokolowski and Dove 2006; Aieta and Oliveira In Prep). The parasite was also recently identified in New Brunswick and Nova Scotia, Canada, with the northernmost part of its range being documented as Cape Breton Island, Nova Scotia (Aieta and Oliveira In Prep).

The parasite is detrimental to the eel's swim bladder and reported effects of the nematode include enlarged abdomens, swim bladder rupture, dilation of the blood vessels in the swim bladder, thickened swim bladder wall, skin ulcers in the abdomen, a red and swollen anus, secondary bacterial infections, decreased swimming ability, and mass mortality (van Banning and Haenen 1990, Molnár et al. 1991; Molnár et al. 1993; Molnár 1994; Ooi et al. 1996; Würtz et al. 1996; Nimeth et al. 2000; Würtz and Taraschewski 2000; Crean et al. 2003; Lefebvre et al. 2004; Gollock et al. 2005a; Sokolowski and Dove 2006). Recent research by Palstra et al. (2007a,b) also indicates that eels severely infected by $A$. crassus are unlikely to reach the spawning grounds. A decrease in recruitment may occur if fewer eels are arriving at the spawning grounds, and ultimately, this could lead to a decrease in the eel population (Barse and Secor 1999; Palstra et al. 2007).

The majority of research on A. crassus in American eels has focused on classic parasite identification, including prevalence, intensity, and mean intensity to determine parasite infection rates (Lefebvre et al. 2002; Sokolowski and Dove 2006). However, studies on European eels have shown that these methods may underestimate the impact of $A$. crassus on eels and do not provide an accurate indication of the severity of the infection (Lefebvre et al. 2002; Lefebvre and Crivelli 2004). This is because previous infections by the parasite may pathologically render the swim bladder unsuitable for re-infection, 
and therefore, the absence of parasites can actually represent a more severe stage of infection (Molnár et al. 1993). Numerous other studies have documented a large number of eels containing no helminthes, but having thickened and damaged swim bladders (van Willigen and Dekker 1989; van Banning and Haenen 1990; Thomas and Ollevier 1992; Molnár et al. 1993), and van Banning and Haenen (1990) concluded that eels with thickened swim bladder walls could no longer support parasites.

Thus, the pathological changes to the swim bladder as identified by the health state of the organ itself may provide a better indication of parasite pressure than just the presence of worms alone (Lefebvre et al. 2002). Pathological changes caused by the parasite include a thickened and opaque swim bladder caused by fibrosis (van Banning and Haenen 1990; Molnar et al. 1993), as well as a swollen and enlarged abdomen that may contain a black mass of decaying worms and a cloudy fluid containing eggs and second-stage juveniles (van Banning and Haenen 1990; Kirk 2003). Furthermore, the pneumatic duct may become dilated and inflamed by worms blocking its opening (Kirk et al. 2000), and eels may have bacterial lesions on the abdomen and a red and swollen anus (Crean et al. 2003). In addition to thickened swim bladders, eels with previous infections may also have pigment accumulation (Molnar et al. 1995), as well as a lumen containing the black slugde of dead worms, digested blood. Debris from the swim bladder wall may also contain encapsulated adults and juveniles (Kirk 2003). In the most severe cases, the lumen collapses and the swim bladder adheres to the surrounding organs (van Banning and Haenen 1990).

Many authors have recognized the importance of quantifying damage to the infected organ instead of studying the infective agent alone (Csaba et al. 1993 and Hartmann 1994, reviewed in Lefebvre et al. 2002; Beregi et al. 1998) and have recommended using histopathological and pathological changes to the swim bladder as an alternative to classic identification methods in eels (Lefebvre et al. 2002; Sokolowski and Dove 2006). One such method was developed by Lefebvre et al. (2002), and involves the use of three criteria, including the transparency and opacity of the swim bladder wall, presence of pigmentation and exudates, and thickness of the swim bladder wall. This macroscopic 
measure of the health state of the swim bladder allows for easy quantification of present and previous infections while taking into account the effect of both the larval and adult stages (Lefebvre et al. 2002).

The objectives of this study include documenting the presence of the nematode in eels from the Shenandoah River, West Virginia and determining the prevalence, mean intensity, and intensity of the infection. In addition, the severity of the A. crassus infection was measured utilizing the swim bladder degenerative index developed by Lefebvre et al. (2002). Ages of eels with current and previous infections were determined and correlations between age and length to parasite infection were analyzed.

\section{Methods}

\section{Study Site}

The Shenandoah River lies mostly in Virginia, with a small portion in West Virginia, and has a catchment size of approximately $7,870 \mathrm{~km}^{2}$. The drainage lies mostly within the Valley and Ridge physiographic province, although some tributaries flow out of the Blue Ridge province (Jenkins and Burkhead 1994). The river is made up of a North Fork and the South Fork; both of which flow for over 250 river kilometers (rkm) before converging at Front Royal, Virginia to form the Shenandoah River. The Shenandoah River joins with the Potomac River at Harper's Ferry, West Virginia, and ultimately drains into the Chesapeake Bay (Figure 2-1).

The Millville hydroelectric dam and eel ladder where the eels were collected is owned and operated by Allegheny Power, and is located on the lower Shenandoah River (Figure 2-1). The dam is $7.24 \mathrm{~km}$ from Harper's Ferry, West Virginia and $249 \mathrm{rkm}$ from the mouth of the Potomac River at the head of tide. This low head dam is $700 \mathrm{~m}$ wide, has a $5 \mathrm{~m}$ head, and has a generating capacity of approximately $1.8 \mathrm{MW}$. The Millville dam eel ladder extends $11 \mathrm{~m}$ on the western end of the dam, and consists of a covered metal sluice that slopes $50^{\circ}$ (Appendix A). American eels are attracted to the eel ladder by an attractant flow located adjacent to the base of the eel ladder (Appendix A). A pool 
created by flashboards on the face of the dam allows eels to distinguish between the spillway and the attractant flows. Movements through the eel ladder are facilitated by three rows of vertically placed PVC pipes situated in a "peg board" pattern that act as a substrate for the eels (Appendix A). The eels pass through the dam via a pipe at the top of the ladder and enter into the collection tank (Appendix A). The tank contains a $2.13 \mathrm{~m}$ long $(60.96 \mathrm{~cm}$ diameter with $6.35 \mathrm{~mm})$ mesh net to constrain the upstream migrants (Appendix A). Nets were checked weekly during the summer to early fall 2006 to 2008.

\section{Parasite Identification}

A total of 242 yellow-phase upstream migrant American eels were examined for the swim bladder nematode parasite, Anguillicola crassus. Eels were captured in the holding tank of the Millville eel ladder during September and October 2006 ( $\mathrm{n}=143)$, August through October $2007(\mathrm{n}=49)$, and June $2008(\mathrm{n}=50)$. After collection, the eels were euthanized with an overdose of clove oil (Eugenol) and were frozen until further swim bladder analysis. Eel total length $(\mathrm{mm})$ was measured, and swim bladders were examined for the presence of the pre-adult and adult parasites. The number of parasites in each eel was recorded, and prevalence, intensity, and mean intensity were calculated. Prevalence was defined as the percent of infected eels, intensity was the total number of nematodes per infected host, and mean intensity was the average number of nematodes per infected hosts in a sample of hosts (Bush et al. 1997). Confidence intervals for the

prevalence data were generated with SAS version 9.1 using the profile likelihood method. Positive identification of the parasite was made based on the descriptions by Moravec and Taraschewski (1988).

\section{Swim Bladder Health Index}

A subsample of 50 eels was examined for macroscopic damage inflicted to the swim bladder by the parasite. A swim bladder degenerative index (SDI) was employed based on methods by Lefebvre et al. (2002). Three criteria were considered:

1). Transparency and opacity of the swim bladder wall 
2). Presence of pigmentation and exudates, including dead worms, erythrocytes, decaying swim bladder tissue, eggs, and $\mathrm{L}_{2} A$. crassus.

3). Thickness of the swim bladder wall, measured using stacked $1 \mathrm{~mm}$ glass slides (Molnár et al. 1994).

Scores of 0 to 2 were assigned to each category with increasing swim bladder degradation. For the transparency of the swim bladder, a score of 0 indicated a normal transparent swim bladder, a 1 indicated intermediate opacity, and a 2 meant that the swim bladder was completely opaque. For the second category, a score of 0 indicated that neither exudate or pigment were present. If either exudate or pigment were found, a score of 1 was assigned, and a 2 was given when both exudates and pigments were present. Eels with swim bladders $<1 \mathrm{~mm}$ were given a score of 0 for swim bladder thickness, while eels with swim bladders $>3 \mathrm{~mm}$ were assigned a score of 2 . These eels had little lumen space remaining. Eels with swim bladder thickness ranging from 1 to 3 $\mathrm{mm}$ were given a 1 . The final cumulative index ranged from 0 to 6 , with a value of 0 corresponding to a healthy intact swim bladder, 1 to 3 being a moderately damaged swim bladder, and 4 to 6 being a severely damaged swim bladder.

\section{Ageing}

American eels with current or previous infections were aged following methods developed by Secor et al. (1992) and Oliveira (1996). Paired sagittal otoliths were removed from the eels and were embedded in epoxy resin. A transverse cut was made using a diamond wafering saw (Buehler Isomet 1000, Germany). Once cut, the sections were placed on a slide with thermoplastic crystalbond glue, ground, and polished. The slides were etched and stained using 2\% EDTA and 5\% toluidine blue. Ages were estimated by counting the number of annual rings along multiple axes, and ages were tripled checked. An additional year was added to the age estimate to account for the larval salt water phase. A regression analysis analyzed the relationship between SDI scores and eel ages. 


\section{Results}

Upstream migrants collected at the Millville dam eel ladder ranged from 200 to $527 \mathrm{~mm}$ $\mathrm{TL}($ mean $=351.5 \pm 3.8 \mathrm{~mm} \mathrm{SE})$. Eels with current and previous infections $(\mathrm{n}=24)$ ranged from $255 \mathrm{~mm}$ to $473 \mathrm{~mm}$ TL $($ mean $=341 \pm 10.9 \mathrm{~mm} \mathrm{SE})$. Those eels showing signs of infection or containing worms ranged from 4 to 11 years of age, with a mean age of $6.9 \pm 1.79 \mathrm{SE}(\mathrm{n}=15)$. A. crassus was the only parasite found in the American eel's swim bladder. Prevalence of the parasite was $2.0 \%$ (lower $\mathrm{CI}=0.007$ and upper $\mathrm{CI}=$ 0.044), and both intensity and mean intensity were 1 (Table 2-1). Results from the swim bladder degenerative index showed a much higher parasite pressure than the classic predictors, with $38 \%$ of the eels showing signs of a previous infection of $A$. crassus. While none of the eels from the Shenandoah River had severely degraded swim bladders, $38 \%$ had moderately damaged swim bladders, and $62 \%$ had healthy swim bladders

(Figures 2-2 and 2-3). The eel age to SDI score regression revealed an $\mathrm{R}^{2}$ value of 0.06 for 21 eels (Figure 2-4).

\section{Discussion}

American eels from the Shenandoah River showed symptoms of previous and ongoing infections of anguillicolosis. This is the first report of $A$. crassus being documented in an inland state, as well as within the upper portions of the Potomac River watershed. Previous reports in the upper and middle Chesapeake Bay indicate higher levels of infections than the 2.0\% found in this study (Barse and Secor 1999; Barse et al. 2001; Geer 2003). In Virginia, Geer (2003) found a 61\% infestation in the York River, 44\% in the Rappahannock River, and 27\% in the James River. Barse et al. (2001) reported prevalence rates of 13 to $82 \%$, with higher levels being found within freshwater sites of the upper Chesapeake Bay. The site located closest to the mouth of the Potomac River 
(St. Jeromes Creek) had infection rates of $40 \%$ for adult parasites and $57.1 \%$ for juveniles (Barse et al. 2001).

The dissemination of the parasite has been documented as being extremely rapid in most watersheds (Kennedy and Fitch 1990; Kirk 2003; Kennedy 2007). Barse et al. (2001) reported that in some Chesapeake Bay sites, prevalence doubled during the two year duration of their study. Therefore, it was hypothesized that infection rates would have increased throughout the duration of this study. However, the presence of the parasites only occurred during the first year of the study in 2006, and infection rates and intensities were much lower than those found in lower reaches of the watershed. This phenomenon was also seen by Machut and Limburg (2008) who found that eels from tributaries of the Hudson River, New York, had much lower parasite infestation rates than in larger river systems. Sampling in the Shenandoah River occurred during the summer when the parasite is thought to be most active (Kennedy and Fitch 1990; Knopf et al. 1998), so if it were present, it should have been located during the three year study. However, it is possible that prevalence may vary seasonally and more research is needed in this area.

Potential reasons for lower prevalence in the Shenandoah River as compared to other Chesapeake Bay sites may include the distance upstream of the Millville eel ladder and length of time for eels to migrate upstream, as well as the presence of dams on the Potomac River. Finally, previously infected eels may have developed an unsuitable environment for further infection. American eels can live in freshwater for up to 30 years (Helfman et al. 1987), and larger and older eels are primarily found upstream in freshwater reaches (Helfman et al. 1987; Morrison et al. 2003). Migrations upstream can take years and the Millville dam eel ladder is located $249 \mathrm{rkm}$ upstream from the head of tide, so the parasite's spread into these areas may be slow. However, age estimates of 42 eels showed that upstream migrants from the Shenandoah River ranged from 4 to 11 years of age ( $\mu=6.7 \pm 0.29 \mathrm{SE}$; Table $2-2$ ), indicating that they could potentially have been infected by the parasite since it was first documented in the Chesapeake Bay in 1997 (Barse and Secor 1999). These ages are consistent with Hildebrand (2005), who 
found that upstream migrants at the Millville dam eel ladder ranged from 3 to 9 years of age.

Physical barriers may also have slowed the spread of the parasite into the Shenandoah River. A total of two dams and one natural falls (Great Falls) exist on the lower Potomac River, and may slow the spread of the parasite. Machut and Limburg (2008) found that the presence of physical barriers reduced A. crassus infection upstream in the Hudson River, New York, and suggest that barriers may play the most important role in determining the distribution of the parasite. American eels become infected by the parasite when consuming an infected paratenic or intermediate host species. Paratenic host species have been identified in European eels as being numerous species of marine, estuarine, and freshwater fish, as well as snails, amphibians and insect larvae (reviewed in Kennedy 2007). Most of these small host species would be unable to circumvent dams, thus upstream migrant eels are primarily responsible for the invasion of the parasite (Machut and Limburg 2008). Machut and Limburg (2008) conclude that while parasite invasion is not halted by physical barriers, it could delay the parasite's arrival into upper portions of watersheds for many years.

Another reason that prevalence may be low in the Shenandoah River is that eels with previously damaged swim bladders may harbor few nematode parasites. Lefebvre et al. (2002) found a non-linear relationship between swim bladder damage and the presence of live worms, and eels could contain parasites, but show no signs of swim bladder damage. In their study, $92 \%$ of the eels showed pathological signs of infection, while only $47 \%$ contained worms. Lefebvre and Crivelli (2004) had similar results; infection rates were lower among eels with severely damaged swim bladders. This is because it may take multiple infections events for pathological changes to occur in the swim bladder (van Banning and Haenen 1990; Molnar et al. 1994; Wurtz and Tarachewski 2000). In their laboratory experiment, Wurtz and Tarachewski (2000) showed that eels infected with up to 40 larvae showed no serious alterations of the swim bladder, and that infections of up to 20 larvae for a period of 20 weeks did not cause a thickening of the swim bladder wall. 
Eels from the Shenandoah River showed signs of having undergone previous infections of the parasite. While only a total of $2.0 \%$ of the eels contained actual parasites within their swim bladder lumen, the use of the swim bladder degenerative index on the subsample of 50 eels indicated that $38 \%$ of the eels had undergone previous infections (Figure 2-2). These eels contained macroscopic damage to the swim bladder including opacity of the swim bladder, black pigment, and the remnants of dead worms. None of the eels in this study contained thickened swim bladder walls (Figure 2-3). This was also described by Molnár et al. (1994), who noted a smoke like opacity of the swim bladder, minor haemorrhages, parasite nodules, and the presence of pigment in some eels that had thin-walled swim bladders. Sokolowski and Dove (2008) found similar pathological results for eels from the Carlls River, Babylon, New York. All of the eels from their study showed previous and ongoing infections of $A$. crassus (Sokolowski and Dove 2008).

Based on the results of the swim bladder degenerative index, those eels that exhibited signs of infection only had moderate damage to their swim bladder and none of the eels had a severe infection (Figure 2-2 and 2-3). It is possible that eels in this watershed are not severely infected, or those with a more severe infection incurred mortality further downstream. Mass mortality caused by the infection in conjunction with other environmental factors has been reported in both farmed and wild eels (Molnar et al. 1991, 1994; Nagasawa et al. 1994). Additionally, previous research has documented that infected eels are less tolerant to high temperatures and hypoxia (Gollock et al. 2005a,b); conditions that frequently occur in the Chesapeake Bay (Anon. 2003). These eels may also be more likely to be caught in fisheries or may be more susceptible to predation (Gollock et al. 2004; Kennedy 2007). Furthermore, eels may have the ability to restore some function of their swim bladders, and even those with intensively infected swim bladders may undergo regeneration (Molnár et al. 1994). These eels have a swim bladder with slight opacity (the result of fibrosis), brownish or black pigmentation left behind at the site of former hemorrhages, and calcified parasitic nodules (Molnar et al. 1994). 
Lebefvre et al. (2002) stated that eels with moderately damaged swim bladders may not contain worms because of an insufficient food supply due to destruction of the swim bladder capillary system on which the worms feed. Also, they may develop an unsuitable habitat for larval development or develop an immune response against the parasite (Lefebvre et al. 2002). Eels with severely affected swim bladder may not contain worms because there is no room remaining in the lumen for the parasite (Lefebvre et al. 2002). This did not appear to be an issue with eels from the Shenandoah River, as none of the eels contained thickened swim bladders.

The health state of the eel's swim bladder is important because damage to the organ by $A$. crassus may impact eel populations by hindering the spawning migration to the Sargasso Sea. The Sargasso Sea is the only place that the eels spawn, so it is possible that the altered ability to migrate could cause a decrease in recruitment (Barse and Secor 1999). The eel's migration to the Sargasso Sea involves long distances at very deep depths, and the eels undergo vertical migrations at night (reviewed in Kirk et al. 2000). As a result, a properly functioning swim bladder is necessary to complete migration (Kirk et al. 2000). Studies by Palstra et al. (2007 a,b) have shown that eels with damaged swim bladders may not be able to complete migrations. However, their study was on the European eel, which has to travel further distances to the spawning grounds than American eels. Furthermore, the parasite may cause a drain on the eel's energy resources during their migrations, as they do not feed during this time and therefore cannot compensate for losses by increased feeding (Aieta and Oliveira In Prep). This can lead to less fat reserves for egg production (Palstra et al. 2007a). Eels may also endure direct stress of the entire duration of its migration (Kennedy 2007) because the parasite can survive for several months in seawater in a host species (Kirk et al. 2000). Additional studies determining the impact of $A$. crassus on American eel populations are needed.

In conclusion, American eels from the Shenandoah River, West Virginia showed signs of both previous and current infections of A. crassus, and continued monitoring of eels in this watershed is warranted. The prevalence and intensity of the parasite in eels from the Shenandoah River is much lower than in many other localities reported in the literature 
including sites located in the Chesapeake Bay (Barse and Secor 1999; Barse et al. 2001; Moser et al 2001; Geer 2003; Morrison and Secor 2003; Rulifison et al. 2004;

Sokolowski and Dove 2006; Machut and Limburg 2008; Aieta and Oliveira In Prep). This may be due to a combination of factors, including the distance upstream of the eel ladder and the presence of natural or manmade barriers on the Potomac River blocking the host species that serve as vectors of the parasite and consequently slowing the spread of the parasite.

Eels may also lose their anguillicolosis infection during upstream migrations. These previously infected eels are either unable to become reinfected due to damage to their swim bladders or there may be no infected host species present to reinfect them. To date, no host species have been identified in the United States, and this information is pertinent in understanding the dissemination of the parasite. Furthermore, the presence of ports (Aieta and Oliveira In Prep) and increased urbanization (Machut and Limburg 2008) have also been associated with trends of increased parasite infections. These factors may also contribute to the distribution of the parasite and should be explored.

As multiple infection events may render the swim bladder unsuitable for habitation by the parasite, the pathological effects of the parasite on the swim bladder may be more important than the actual presence of the parasite itself. Therefore, the use of the swim bladder degenerative index developed by Lefebvre et al. (2002) may more accurately characterize the infection by taking into account the history of the infection by the parasite, as well as measuring both adult and larval impacts. This method should be utilized in conjunction with classic parasite identification when determining the impact of A. crassus on American eels.

\section{Literature Cited}

Anon. 2003. Chapter 3, Dissolved Oxygen Criteria, p. 7-100 in: Ambient Water Quality Criteria for Dissolved Oxygen, Water Clarity and Chlorophyll a for the Chesapeake Bay and its tributaries. US EPA 903-R-03-002, Chesapeake Bay Program Office, Annapolis, Maryland. 
Aieta, A.E. and K. Oliveira. In Prep. The distribution, prevalence, and intensity of the swim bladder parasite Anguillicola crassus in New England and eastern Canada. Diseases of Aquatic Organisms.

Atlantic States Marine Fisheries Commission (ASMFC). 2007. Review of the Atlantic States Marine Fisheries Commission fishery management plan for American eel (Anguilla rostrata).

Barse, A.M. and D.H. Secor. 1999. An exotic nematode parasite of the American eel. Fisheries 24: 6-10.

Barse, A.M., S.A. McGuire, M.A. Vinores, L.E. Eierman, and J.A. Weeder. 2001. The swim bladder nematode Anguillicola crassus in American eels (Anguilla rostrata) from middle and upper regions of the Chesapeake Bay. Journal of Parasitology 87(6): 1366-1370.

Beregi, A., K. Molnár, L. Békési, and Cs. Székely. 1998. Radiodiagnostic method for studying swimbladder inflammation caused by Anguillicola crassus (Nematoda: Dracunculoidea). Diseases of Aquatic Organisms 34: 155-160.

Bush, A.O., K.D. Lafferty, J.M. Lottz, and A.W. Shostak. 1997. Parasitology meets ecology on its own terms: Margolis et al. revisited. Journal of Parasitology 83: $575-583$.

Casselman, J.M. 2003. Dynamics of resources of the American eel, Anguilla rostrata: declining abundance in the 1990's. Pages 255-274 in K. Aida, K. Tsukamoto, K. Yamauchi, editors. Eel Biology. Springer-Verlag, Toyoko.

Casselman, J.M. 2005. American eel dynamics and abundance: a fish resource in unprecedented decline. J.M. Casselman and D. Cairns (eds.) International Eel Symposium, American Fisheries Society Special Publication. In review.

Castonguay, M., P.V. Hodson, C.M. Couillard, M.J. Eckersley, J.-D. Dutil and G. Verreault. 1994a. Why is recruitment of the American eel, Anguilla rostrata, declining in the St. Lawrence River and Gulf? Canadian Journal of Fisheries and Aquatic Science 51: 479-488.

Castonguay, M., P.V. Hodson, C. Moriarty, K.F. Drinkwater, and B.M. Jessop. 1994b. Is there a role in the ocean environment in American and European eel decline? Fisheries Oceanography 3(3): 197-203.

COSEWIC 2006. COSEWIC assessment and status report on the American eel Anguilla rostrata in Canada. Committee on the Status of Endangered Wildlife in Canada. Ottawa. $x+71$ pp. (www.sararegistry.gc.ca/status/status e.cfm).

Crean, S.R., J.T.A. Dick, D.W. Evans, R.W. Elwood, and R.S. Rosell. 2003. Anal 
redness in European eels as an indicator of infection by the swimbladder nematode Anguillicola crassus. Journal of Fish Biology 62: 482-485.

Csaba, G., M. Láng, G. Salyi, J. Ramotsa, R. Glávits, and F. Ratz. 1993. The nematode Anguillicola crassus (Nematoda, Anguillicolidae) and its role in the death of eels in Lake Balaton during 1991. Magyar Állatorvosok Lapja 48: 11-21. In Lefebvre et al. 2002.

Fries, L.T., D.J. Williams, and S.K. Johnson. 1996. Occurrence of Anguillicola crassus, an exotic parasitic swim bladder nematode of eels, in southeastern United States. Transactions of the American Fisheries Society 125: 794-797.

Geer, P.J. 2003. Distribution, relative abundance, and habitat use of American eel Anguilla rostrata in the Virginia portion of the Chesapeake Bay. American Fisheries Society Symposium 33: 101-115.

Gollock, M.J., C.R. Kennedy, and J.A. Brown. 2005a. European eels, Anguilla anguilla (L.), infected with Anguillicola crassus exhibit a more pronounced stress response to severe hypoxia than uninfected eels. Journal of Fish Diseases 28: 429-436.

Gollock, M.J., C.R. Kennedy, and J.A. Brown. 2005b. Physiological responses to acute temperature increases in European eels, Anguilla anguilla infected with Anguillicola crassus. Diseases of Aquatic Organisms 64: 223-228.

Gollock, M.J., C.R. Kennedy, E.S. Quabius, and J.A. Brown. 2004. The effect of parasitism of European eels with the nematode Anguillicola crassus on the impact of netting and aerial exposure. Aquaculture 233: 45-54.

Haro, A., W. Richkus, K. Whalen, A. Hoar., W.-D, Busch, S. Lary, T. Brush, and D. Dixon. 2000. Population decline of the American eel: Implications for research and management. Fisheries 25(9): 7-16.

Hartmann, F. (1994). Untersuchungen zur biologie, epidemiologie und schadwirkung von Anguillicola crassus Kuwahara, Niimi \& Itagaki 1974 (Nematoda), einem blutsaugenden parasiten in der schwimmblase des Europa ischen aals (Anguilla anguilla). Aachen: Shaker Verlag. In Lefebvre et al. 2002

Helfman, G.S., D.E. Facey, L.S. Hales Jr., and E.L. Bozeman Jr. 1987. Reproductive ecology of the American eel. American Fisheries Society Symposium 1: 42-56.

Hildebrand, H. 2005. Size, age composition, and upstream migration of American eels at Millville Dam eel ladder, Shenandoah River, West Virginia. Master's Thesis, West Virginia University, Morgantown, WV.

Höglund, J. and K. Thomas. 1992. The black goby Gobius niger as a potential paratenic 
host for the parasitic nematode Anguillicola crassus at a thermal effluent of the Baltic. Diseases of Aquatic Organisms 12: 175-180.

Jenkins, R. E., and N. M. Burkhead. 1994. Freshwater Fishes of Virginia. American Fisheries Society, Bethesda, Maryland.

Kennedy, C.R. 2007. The pathogenic helminth parasites of eels. Journal of Fish Diseases 30: 319-334.

Kennedy, C.R. and D.J. Fitch. 1990. Colonization, larval survival and epidermiology of the nematode, Anguillicola crassus, in Britain. Journal of Fish Biology 36: 117131.

Kirk, R.S. 2003. The impact of Anguillicola crassus on European eels. Fisheries Management and Ecology 10: 385-394.

Kirk, R.S., C.R. Kennedy, and J.W. Lewis. 2000. Survival and transmission of Anguillicola crassus Kuwahara, Niimi \& Itagaki, 1974 (Nematoda) in seawater eels. Parasitology 120: 289-295.

Lefebvre, F.S., and A.J. Crivelli. 2004. Anguillicolosis: dynamics of the infection over two decades. Diseases of Aquatic Organisms 62: 227-232.

Lefebvre, F.S., B. Mounaix, G. Puizat, and A.J. Crivelli. 2004. Impacts of the swimbladder nematode Anguillicola crassus on Anguilla anguilla: variations in liver and spleen mass. Journal of Fish Biology 64: 435-447.

Lefebvre, F., P. Contournet, and A.J. Crivelli. 2002. The health state of the eel swimbladder as a measure of parasite pressure by Anguillicola crassus. Parasitology 124: 457-463.

Machut, L.S. and K.E. Limburg. 2008. Anguillicola crassus infection in Anguilla rostrata from small tributaries of the Hudson River watershed, New York, USA. Diseases of Aquatic Organisms 79: 37-45.

Molnár, K. 1994. Formation of parasitic nodules in the swim bladder and intestinal walls of the eel, Anguilla anguilla due to infections with larval stages of Anguillicola crassus. Diseases of Aquatic Organisms 20: 163-170.

Molnár, K., C.S. Székely, and F. Baska. 1991. Mass mortality of eels in Lake Balaton due to Anguillicola crassus infection. Bulletin of the European Association of Fish Pathologists 11: 211-212.

Molnár, K., F. Baska, Gy. Csaba, R. Glávits, and Cs. Székely. 1993. Pathological and 
histopathological studies of the swim bladder of eels Anguilla anguilla infected by Anguillicola crassus (Nematoda: Dracunculoidea). Diseases of Aquatic Organisms 15: 41-50.

Molnár, K., Cs. Székely, and M. Perényi. 1994. Dynamics of Anguillicola crassus (Nematoda: Dracunculoidae) infection in eels of Lake Balaton, Hungary. Folia Parasitologica 41: 193-202.

Molnár, K., J. Szakolczai, and F. Vetési. 1995. Histological changes in the swim bladder wall of eels due to abnormal location of adults and second stage larvae of Anguillicola crassus. Acta Veterinaria Hungarica 43: 125-137.

Moravec, F. and H. Taraschewski. 1988. Revision of the genus Anguillicola Yamaguti, 1935 (nematoda: Anguillicolidae) of the swimbladder of eels, including descriptions of two new species, A. novaezelandiae SP. N. and A. papernai SP. N. Folia Parasitologica 35: 125-146.

Morrison, W.E. and D.H. Secor. 2003. Demographic attributes of yellow-phase American eels (Anguilla rostrata) in the Hudson River estuary. Canadian Journal of Fisheries and Aquatic Science 60: 1487-1501.

Morrison, W.E., D.H. Secor, P.M. Piccoli. 2003. Estuarine habitat use by Hudson River American eels as determined by otolith strontium: calcium ratios. American Fisheries Society Symposium 33: 87-99.

Moser, M.L., W.S. Patrick, and J.U. Crutchfield, Jr. 2001. Infection of American eels, Anguilla rostrata, by and introduced nematode parasite, Anguillicola crassus, in North Carolina. Copia 3: 848-853.

Nagasawa, K., Y-G. Kim, and H. Hirose. 1994. Anguillicola crassus and A. globiceps (Nematoda: Dracunculoidea) parasitic in the swim bladder of eels (Anguilla japonica and A. anguilla) in East Asia: A review. Folia Parasitologica 41: 127137.

Nimeth, K., P. Zwerger, J. Würtz, W. Salvenmoser, and B. Pelster. 2000. Infection of the glass-eel swimbladder with the nematode Anguillicola crassus. Parasitology 121: $75-83$.

Oliveira, K. 1996. Field validation of annular growth rings in the American eel, Anguilla rostrata, using tetracycline-marked otoliths. Fishery Bulletin 94: 186189.

Ooi, H.-K., W.-S. Wang, H.-Y. Chang, C.-H. Wu, C.-C. Lin, and M.-T. Hsieh. 1996. An epizootic of anguillicolosis in cultured American eels in Taiwan. Journal of Aquatic Animal Health 8: 163-166. 
Palstra, A.P., D.F.M. Heppener, V.J.T. van Ginneken, C. Székely, and G.E.E.J.M. van den Thillart. 2007a. Swimming performance of silver eels is severely impaired by the swim-bladder parasite Anguillicola crassus. Journal of Experimental Marion Biology and Ecology 352: 244-256.

Palstra, A., D. Curiel, M. Fekkes, M. de Bakker, C. Székely, V.J.T. van Ginneken, and G.E.E.J.M. van den Thillart. 2007b. Swimming stimulates oocyte development in European eel. Aquaculture 270: 321-332.

Rulifson, R.A., C. Cahoon, and J.L. Cudney. 2004. Critical habitat assessment and population demographics of the American eel fishery in Northwestern Pamlico Sound, North Carolina. Final Report, Fishery Resource Grant Program, Project 02-EP-13.

Secor, D.H., J.M. Dean, and E. Laban. 1992. Otolith removal and preparation for microstructural examination. Pages 119-127 in D.K. Stevenson and S.E. Compana (eds.), Otolith microstructure examination and analysis. Canada Special Publications on Fisheries and Aquatic Science 117.

Sokolowski, M.S. and A.D.M. Dove. 2006. Histopathological examination of wild American eels infected with Anguillicola crassus. Journal of Aquatic Animal Health 18: 257-262.

Thomas, K. and F. Ollevier. 1992. Population biology of Anguillicola crassus in the final host Anguilla anguilla. Diseases of Aquatic Organisms 14: 163-170.

van Banning, P. and O.L.M. Haenen. 1990. Effects of the swim bladder nematode Anguillicola crassus in wild and farmed eel, anguilla anguilla. Pages 317-330 in F.O. Perkins and T.C. Cheng (eds.). Pathology in Marine Science. Proceedings of the Third International Colloquium on Pathology in Marine Aquaculture held in Gloucester Point, Virginia, 2-6 October 1998. Academic Press, Inc., San Diego, CA.

van Willigen, J. and W. Dekker. 1989. 1988 update on Anguillicola in Dutch outdoor waters. EIFAC (FAO) Working Party on Eel. Oporto, Portugal, May 29 to June 3, 1989. 8 pp. In Molnar et al. 1994.

Würtz, J. and H. Taraschewski. 2000. Histopathological changes in the swimbladder wall of the European eel Anguilla anguilla due to infections with Anguillicola crassus. Diseases of Aquatic Organisms 39: 121-134.

Würtz, J., H. Taraschewski, and B. Pelster. 1996. Changes in the gas composition of the swimbladder of the European eel (Anguilla anguilla) infected with Anguillicola crassus (Nematoda). Parasitology 112: 233-238. 
Table 2-1: Summary of prevalence and intensity of American eels collected from the Millville eel ladder on the Shenandoah River, WV.

\begin{tabular}{ccccccc}
\hline Year & $\begin{array}{c}\text { Eels } \\
\text { Collected } \\
\mathrm{n}\end{array}$ & $\begin{array}{c}\text { Length }(\mathrm{mm} \pm \\
\text { SE) }\end{array}$ & $\begin{array}{c}\text { Infected } \\
\text { Eels } \\
\mathrm{N}\end{array}$ & Prevalence & Intensity & Mean Intensity \\
\hline 2006 & 143 & $375.9 \pm 49.1$ & 5 & $3.4 \%$ & 1 & 1 \\
2007 & 49 & $315.6 \pm 57.6$ & 0 & $0 \%$ & 0 & 0 \\
2008 & 50 & $315.6 \pm 46.2$ & 0 & $0 \%$ & 0 & 0 \\
Total & 242 & $351.5 \pm 58.8$ & 5 & $2.0 \%$ & 1 & 1 \\
\hline
\end{tabular}

Table 2-2: Summary of ages and lengths of a subsample of 42 American eels from the Shenandoah River. Of the 42 eels, 15 were those that either contained parasites in their swim bladder or eels that showed signs of a previous infection.

\begin{tabular}{cccccccccccc}
\hline \multicolumn{3}{c}{ All Eels } & \multicolumn{4}{c}{ Infected Eels } & \multicolumn{3}{c}{ Non-Infected Eels } \\
\hline Age & $\mathrm{N}$ & $\begin{array}{c}\text { Mean } \\
\text { length } \\
\text { (TL mm) }\end{array}$ & SE & Age & N & $\begin{array}{c}\text { Mean } \\
\text { length } \\
\text { (TL mm) }\end{array}$ & SE & Age & N & $\begin{array}{c}\text { Mean } \\
\text { length } \\
\text { (TL mm) })\end{array}$ & SE \\
\hline 4 & 5 & 298.6 & 22.6 & 4 & 1 & 279 & - & 4 & 4 & 303.5 & 28.5 \\
5 & 7 & 317.1 & 16.0 & 5 & 4 & 302.8 & 19.8 & 5 & 3 & 336.3 & 26.3 \\
6 & 6 & 351.2 & 21.3 & 6 & 2 & 352 & 28 & 6 & 4 & 350.8 & 31.7 \\
7 & 13 & 326 & 13.3 & 7 & 3 & 287.3 & 2.7 & 7 & 10 & 337.6 & 15.5 \\
8 & 4 & 408.8 & 22.4 & 8 & 2 & 397.5 & 23.5 & 8 & 2 & 420 & 33.2 \\
9 & 2 & 363.5 & 86.5 & 9 & 0 & - & - & 9 & 2 & 363.5 & 61.2 \\
10 & 4 & 353.5 & 23.0 & 10 & 2 & 314 & 6 & 10 & 2 & 393 & 5 \\
11 & 1 & 420 & - & 11 & 1 & 420 & - & 11 & 0 & - & - \\
\hline
\end{tabular}



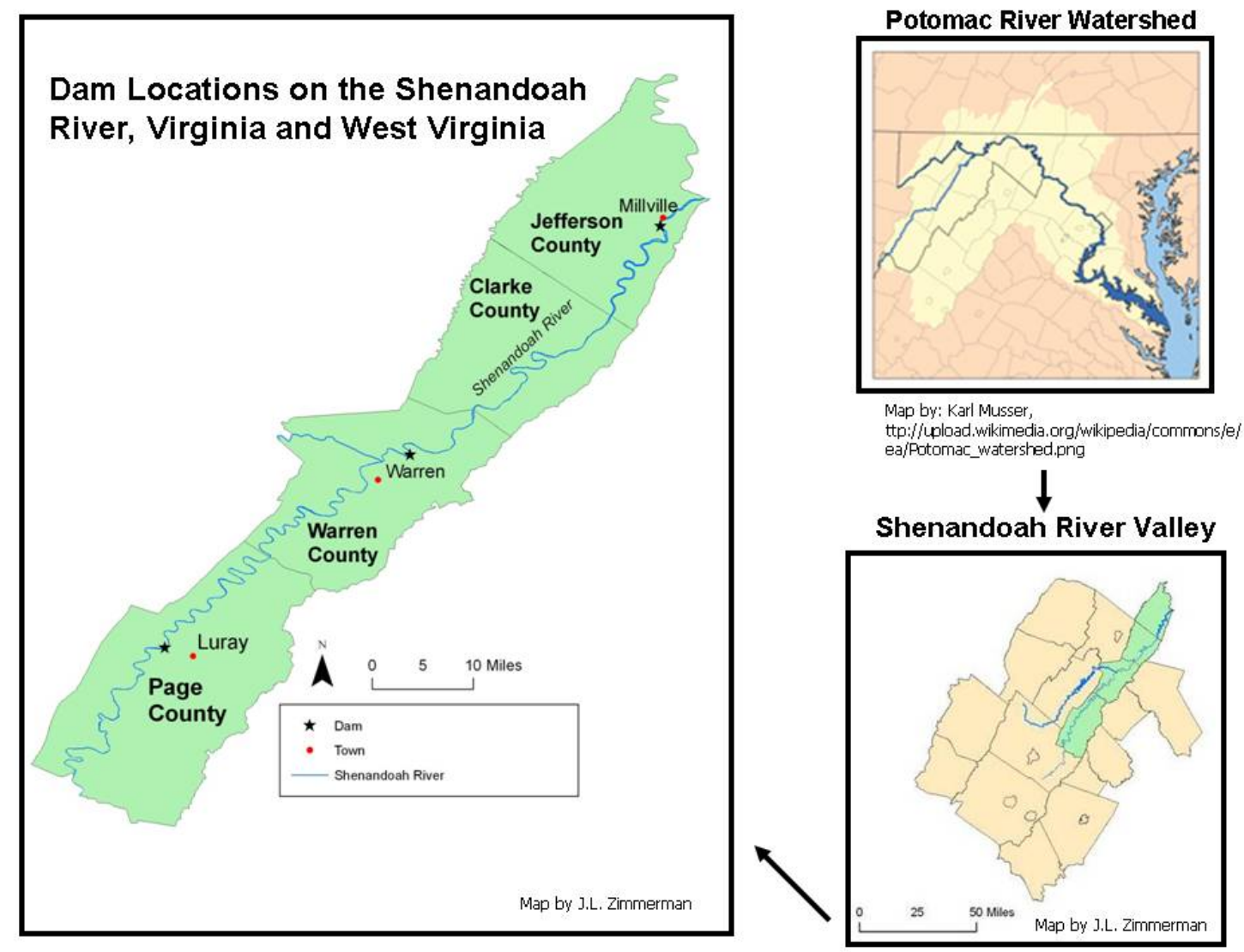

Figure 2-1: Location of the eel ladder at Millville Dam on the Shenandoah River, WV. 


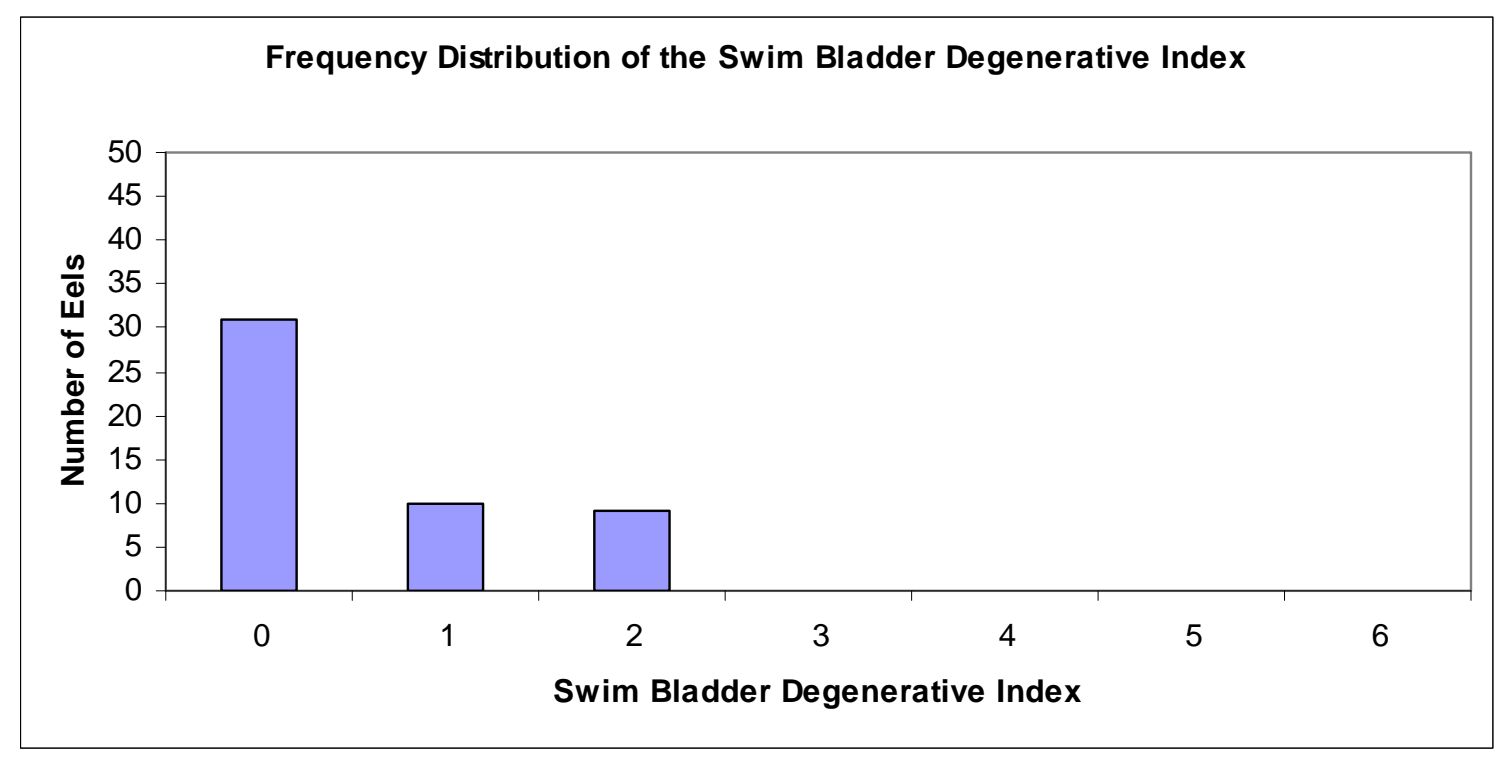

Figure 2-2: Frequency distribution of the swim bladder degenerative index (SDI). The SDI was used to determine the impact of $A$. crassus on the swim bladder of upstream migrant American eels captured at the Millville eel ladder on the Shenandoah River. A value of 0 corresponds to a healthy intact swim bladder, 1 to 3 is a moderately damaged swim bladder, and 4 to 6 is a severely damaged swim bladder.

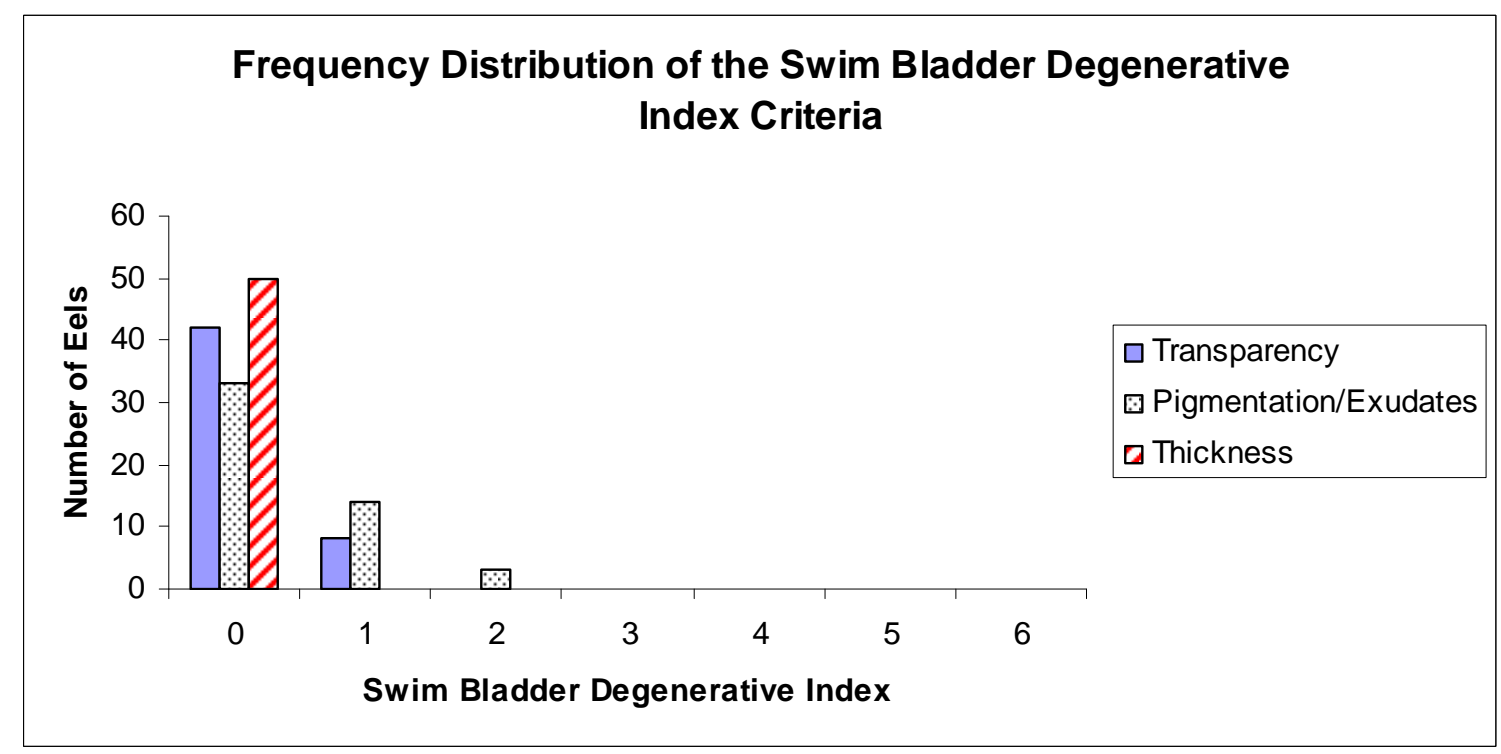

Figure 2-3: Frequency distribution of the swim bladder degenerative index criteria including the transparency of the swim bladder, the presence of pigmentation and exudates, and the thickness of the swim bladder. The SDI was used to determine the impact of $A$. crassus on the swim bladder of upstream migrant American eels captured at the Millville eel ladder on the Shenandoah River. Scores ranged from 0 to 6 , with a 0 indicating no pathological signs of infection were observed and 6 denoting extreme abnormalities. 


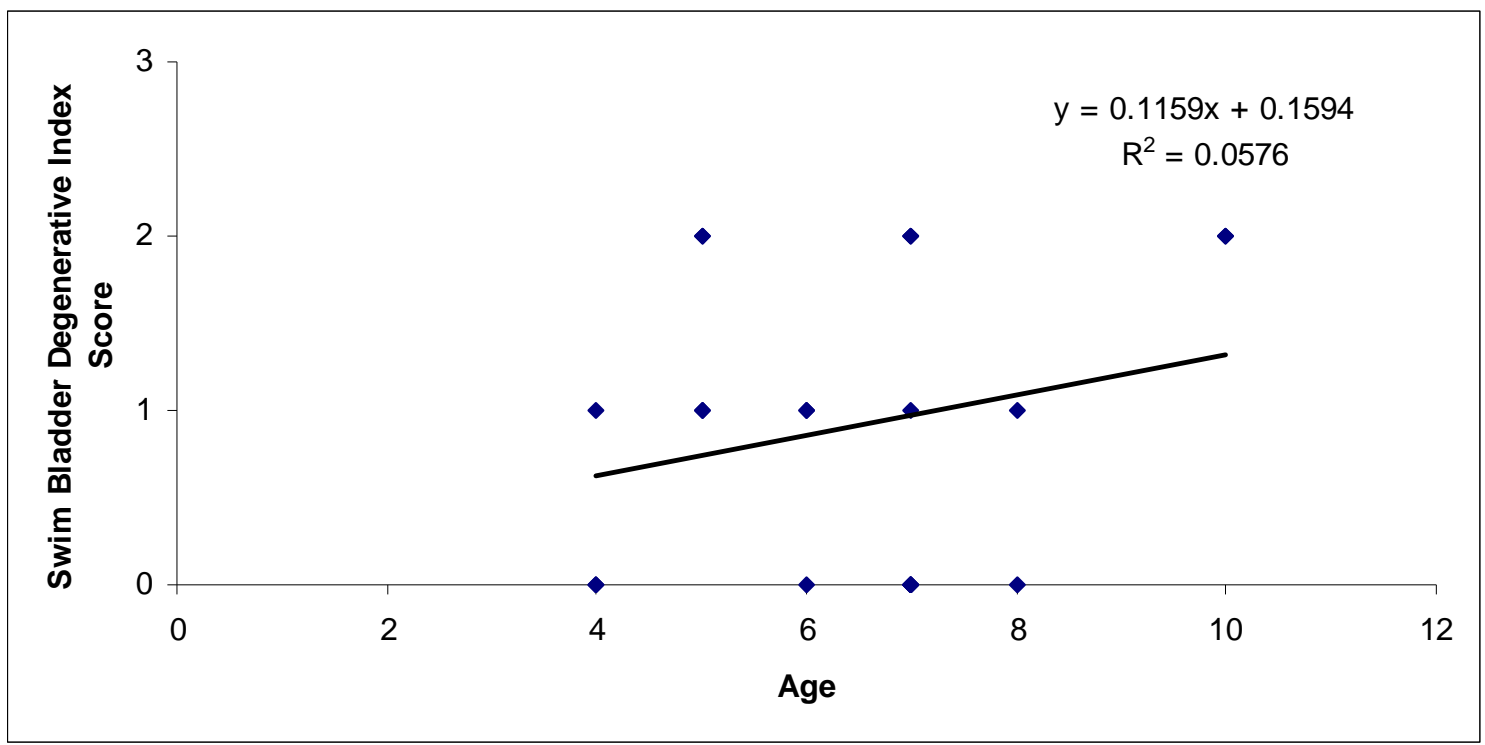

Figure 2-1: Age to Swim bladder degenerative index score relationships of American eels from the Millville Dam eel ladder, Shenandoah River, WV. 


\section{Chapter 3: Pit Tag Retention in Small (205-370 mm) American Eels}

\section{Abstract}

Passive integrated transponders (PIT tags) are commonly used in ecological studies of aquatic and terrestrial animals. Researchers have used PIT tags in American eels (Anguilla rostrata) to study growth rates, home range size, and migration. The placement of PIT tags within the body of American eels differs among studies, including insertion in the dorsal musculature behind the head, the dorsal musculature near the dorsal fin origin, and the abdominal cavity. Retention rates of PIT tags for American eels are reported in the literature, but researchers have not previously compared and reported tag retention rates among different tagging locations. The objective of this study was to compare retention rates of PIT tags placed in the dorsal musculature behind the head, the dorsal musculature near the dorsal fin origin, and the abdominal cavity of American eels. Eighteen American eels were collected during fall 2006 from the Millville dam eel ladder on the lower Shenandoah River, West Virginia. Each eel was PIT tagged in three locations and tag retention was monitored for 9 weeks. Tag retention in the dorsal musculature near the dorsal fin origin (100\%) and the abdominal cavity $(100 \%)$ were higher than the retention rate of tags placed behind the head (88\%). Our results, consistent with previous literature, support an overall high retention rate of PIT tags in American eels. Previous studies have primarily focused on large eels and our results document high tag retention rates in small eels (205-370 $\mathrm{mm}$ total length).

\section{Introduction}

Passive integrated transponders (PIT tags) are small microchips with coiled antennas enclosed in biocompatible glass. These tags are typically injected into the body cavity or muscle tissue of an animal. Researchers have used PIT tags on many taxa, such as bats (Eptesicus fuscus; Neubaum et al. 2005), crayfish (Pacifastacus leniusculus; Bubb et al. 2002), ferrets (Mustela putorius furo and Mustela nigripes; Fagerstone and Johns 1987), frogs (Rana muscosa; Matthews 2003), king crabs (Paralithodes camtschaticus; Donaldson et al. 1992), penguins (Pygoscelis adeliae; Ballard et al. 2001), quail (Colinus virginianus; Carver et al. 1999), rattlesnakes (Sistrurus miliarius; Jemison et al. 1995), seals (Mirounga leonine; Galimberti et al. 2000), sea turtles (Chelonia mydas and Caretta 
caretta; Broderick and Godley 1999), and sea urchins (Strongylocentrotus franciscanus; Shelton et al. 2006). These "passive" tags remain dormant in the body cavity or muscle tissue until activated by a handheld or automated reader. The reader sends a low frequency signal to the microchip, which activates the tag, and retrieves an individual alphanumeric sequence code. These sequence codes are unique to each tag, thus allowing researchers to identify individual animals (Prentice et al. 1990a).

In fisheries, PIT tags were first used for mark-recapture studies of coho and Chinook salmon (Oncorhynchus kisutch and Oncorhynchus tshawytsch; Prentice and Park 1984). Since this initial study, PIT tags have gained extensive use in fisheries research, including studies of arctic grayling (Thymallus arcticus; Buzby and Deegan 1999), black rockfish (Sebastes melanops; Parker and Rankin 2003), creek chub (Semotilus atromaculatus; Smithson and Johnston 1999), damselfish (Pomacentrus amboinensis; McCormick and Smith 2004), lampreys (Petromyzon marinus; Quintella et al. 2005), red drum (Sciaenops ocellatus; Jenkins and Smith 1990), sculpin (Cottus bairdii; Ruetz et al. 2006), striped bass (Morone saxatilis; Jenkins and Smith 1990), sturgeon (Acipenser oxyrinchus desotoi; Clugston 1996), and sunfish (Lepomis cyanellus and Lepomis megalotis; Smithson and Johnston 1999). Researchers have also used PIT tags to study movements of fishes associated with fishways and dams, as PIT tag readers can be set up directly where fish pass, allowing for scanning of individual fish (Prentice et al. 1990b; Burke and Jepson 2006).

PIT tags have many advantages to other methods of mark-recapture in fisheries, including fin clipping, branding, use of dyes and pigments, and coded wire tags (Harvey and Campbell 1989; Jenkins and Smith 1990; Prentice et al. 1990b). These other tags suffer from faded identification numbers, unrecognizable marks, tag loss, or the need to sacrifice the study animal to obtain information (Prentice and Park 1984; McFarlane et al. 1990; Gibbons and Andrews 2004). Handling time of tagged animals is reduced with PIT tags relative to other forms of tagging (Prentice et al. 1990b). Further, PIT tags are internal and often permanent (except for tag loss), have little influence on animal behaviors, and allow for identification of individuals (Prentice and Park 1984; Jenkins 
and Smith 1990; Prentice et al. 1990a). Also, PIT tags often have high tag detection rates (95-100\%), as well as reader accuracy near 100\% (Prentice et al. 1990b; McCutcheon et al. 1994).

Despite the overall high success rate of PIT tags, tag retention rates differ among species and the area of tag placement. Tag loss ranges from $0 \%$ in largemouth bass (Micropterus salmoides; Harvey and Campbell 1989) to $99.4 \%$ in paddlefish (Polyodon spathula; Onders et al. 2001). Most studies on bony fish, however, report tag loss rates of less than 5\% (Prentice and Park 1984; Moore 1992; Ombredane et al. 1998; Das Mahaptra et al. 2001; Dare 2003). In American eel (Anguilla rostrata) studies, PIT tag retention rates range from $89 \%$ to $100 \%$ (Table 3-1; Morrison and Secor 2003; Verdon and Desrochers 2003; Verdon et al. 2003; Thomas 2006). Tag loss can result from incorrect tagging techniques, rejection of the tag by the animal's body, or migration of the tag within the body (Gibbons and Andrews 2004). Tag loss is a serious problem for mark-recapture studies (McFarlane et al. 1990). For example, recaptured animals (with lost tags) counted as newly-tagged animals bias the ratio of recaptured animals to tagged animals (Arnason and Mills 1981; Stobo and Horne 1994; Schwarz and Stobo 1999), although biases associated with tag loss are correctable with estimates of retention rates.

PIT tag retention is influenced, in part, by tag placement (Elbin and Burger 1994; Gibbons and Andrews 2004). Gibbons and Andrews (2004) state that "the success of tagging technique is determined almost solely by placement of the tag", and recommend that researchers perform pilot tag retention studies before using PIT tags. Studies of PIT tag retention in American eel have not compared different tagging locations. Our study objective was to quantify retention rates of three PIT tag placements in American eels. This research was a pilot study to determine PIT tag placement for a study of upstream migration in American eels, but results will also apply to other PIT tag studies of American eels. 


\section{Materials and Methods}

\section{Collection and Laboratory Setting}

Eighteen American eels were collected in October 2006 from the Millville Dam eel ladder on the lower Shenandoah River, West Virginia. Eels were collected in a $4.76 \mathrm{~mm}$

mesh net attached to the upstream end of the eel ladder. Once in the laboratory, eels were held in a $380 \mathrm{~L}$ recirculation-system holding tank with constant water flow, and fed minnows and crayfish. Water temperatures within the tank ranged from $13.4^{\circ} \mathrm{C}-18.8^{\circ} \mathrm{C}$ over the duration of the study. The eels were acclimated to this tank setting for two months prior to the start of the study.

\section{PIT Tagging Methods}

Before insertion of PIT tags, eels were anesthetized with a clove oil solution $\left(10 \mathrm{~L} \mathrm{H}_{2} 0\right.$, $1.2 \mathrm{ml}$ clove oil, and $12 \mathrm{ml}$ of ethanol) following methods of Anderson et al. (1997). Prior to tagging, eels remained in the clove oil solution for approximately 5 minutes. Each eel was tagged in three separate locations with PIT tags (Destron-Fearing TX1411L, size $12.50 \mathrm{~mm}$ X $2.07 \mathrm{~mm}$ ) using a modified syringe with a 12 gauge needle. Tagging locations included the dorsal musculature near the dorsal fin origin, the abdominal cavity, and the dorsal musculature behind the head (Figure 3-1 and Appendix B). Eel lengths and corresponding individual PIT tag numbers were recorded. The tagging wounds were left unclosed to heal naturally. After being tagged, the eels were placed in an aerated recovery tank for approximately 20 minutes before being returned to the holding tank.

PIT tag retention was checked weekly for a period of 5 weeks and then bi-weekly for 4 additional weeks, for a total of 9 weeks. To check tag retention, eels were removed from the tank and anesthetized (as described above). A handheld PIT tag reader (DestronFearing, Mini Portable Reader 2, Part \# 800-0249-01) was used to check each eel for all three PIT tags. After tag checks, eels were placed in a recovery tank for 20 minutes 
before return to the holding tank. Shed tags were located in the substrate of the holding tank following the study. Confidence intervals for tag retention data were generated with SAS version 9.1 using the profile likelihood method.

\section{Results}

Eels ranged in length from 205 to $370 \mathrm{~mm}$, with a mean length of $311.7 \pm 39.0 \mathrm{SE} \mathrm{mm}$ (Table 3-2). Tag retention was relatively high in all three tagging locations. Retention rates were highest $(100 \%)$ in the dorsal musculature near the dorsal fin origin and in the abdominal cavity (lower $\mathrm{CI}=0.885$ ). Lower retention rates $(88 \%)$ for the dorsal musculature near the head resulted from two lost tags within the first week of the study (lower $\mathrm{CI}=0.695$ and upper $\mathrm{CI}=0.985)($ Table 3-2). Both shed tags were located in the tank, confirming tag loss and not tag or scanner malfunctions.

\section{Discussion}

PIT tag retention in this study was $100 \%$ for American eels tagged in the dorsal musculature and in the body cavity, and $88 \%$ for eels tagged behind the head. These results are similar to those published in the literature (Table 3-1). In a 6-month laboratory study, Thomas (2006) also found 100\% retention for American eels tagged in the dorsal musculature. Conversely, Verdon et al. (2003) reported a lower retention rate for eels tagged in the dorsal musculature, with a success rate of $93.9 \%$. Morrison and Secor (2003) also found lower retention rates (89\%) for eels tagged in the abdominal cavity relative to our study.

Estimates of PIT tag retention rates from laboratory studies may overestimate retention rates from natural environments. Lower retention rates reported by Verdon et al. (2003) and Morrison and Secor (2003) were from eels in riverine environments, and eels within rivers may have a higher likelihood of tag loss than those in captivity (Thomas 2006). The range of water temperatures $\left(13.4^{\circ} \mathrm{C}-18.8^{\circ} \mathrm{C}\right)$ during this study may have reduced 
eel activity. Temperature triggers activity in eels, and temperatures $\geq 20^{\circ} \mathrm{C}$ are associated with peak increases in eel activity (Knights and White 1998; Verdon and Desrochers 2003; Verdon et al. 2003). Eels that are migrating upstream, like those reported by Verdon et al. (2003), may be more likely to lose tags than more sedentary eels in laboratory holding tanks.

Thomas et al. (2006) suggested that retention rates may be influenced by eel size. Thomas et al. (2006) tagged eels $\geq 500 \mathrm{~mm}$; larger than mean eel lengths from other PIT tag studies (Table 3-1). Verdon and Desrochers (2003) found higher retention rates (98\%) for eels tagged behind the head, as compared to this study (88\%). The larger mean length $(464.8 \mathrm{~mm})$ of the eels tagged by Verdon and Desrochers (2003) relative to our study $(311.6 \mathrm{~mm})$ may explain differences in retention rates. The low mean length of the eels in our study $(311.7 \pm 39 \mathrm{~mm} \mathrm{SE})$, however, indicates that high tag retention is possible in small eels.

Loss of PIT tags may result from incorrect tagging technique or rejection of the tag by the animal's body. Also, migration of a tag within an animal's body, and tag or scanner malfunctions mimic tag loss, because undetected tags are assumed lost. Most tag losses result from improper implantation of the tag (Gibbons and Andrews 2004). Dare (2003) attributed inexperience of the tagging crew to high tag loss in spring Chinook salmon (Oncorhynchus tshawytscha), because tag loss decreased with an increase in experience of the tagging crew (Dare 2003). Tag migration may increase with the size of the tagged animal (Gibbons and Andrews 2004). Camper and Dixon (1988) reported tag migration in $44 \%$ of the kingsnakes (Lampropeltis getulus holbrooki) and $71 \%$ of collared lizards (Crotaphytus c. collaris) with abdominally-placed PIT tags. Prentice and Park (1984) reported migration of abdominally-paced PIT tags in 5\% of juvenile fall Chinook salmon (Oncorhynchus tshawytscha). Tag migration, however, is unlikely to influence tag detection in American eels, because tag readers can easily scan the entire body of the eel.

Tag loss in our study probably resulted from either improper implantation or tag rejection. The two tags shed during the first week of this study likely exited through the 
tagging wound. Feldheim et al. (2002) found that lemon sharks (Negaprion brevirostris) shed PIT tags through unclosed wounds a few days after tagging. Prentice and Park (1984) also reported shed tags (through the tagging wound) in coho and Chinook salmon (Oncorhynchus kisutch and Oncorhynchus tshawytscha) within a few days after tag placement.

Our results support two body locations for PIT tag placement in American eels; the abdominal cavity and the dorsal musculature near the dorsal fin origin. Tags inserted into the abdominal cavity, however, may increase risk of mortality in American eels owing to the proximity of the tagging syringe needle to internal organs, but we did not experience tagging mortality. Our study was relatively short-term (9-weeks) and longer-term studies are needed to further understand differential rates of retention among tagging locations. Additionally, laboratory-based studies restrict eel movements and provide a relatively benign environment, hence, our laboratory results may not allow inference to tagretention rates of American eels within riverine habitats.

\section{Aknowledgements}

Funding was provided by Allegheny Energy Supply and the West Virginia Division of Natural Resources. Reference to trade names does not imply government endorsement of commercial products.

\section{Literature Cited}

Anderson, W.G., R.S. McKinley, and M. Colavecchia. 1997. The use of clove oil as an anesthetic for rainbow trout and its effects on swimming performance. N. Am. J. Fish. Manage. 17: 301-307.

Arnason, A.N. and K.H. Mills. 1981. Bias and loss of precision due to tag loss in JollySeber estimates for mark-recapture experiments. Can. J. Fish. Aquat. Sci. 38: 1077-1095.

Ballard, G., D.G. Ainley, C.A. Ribic, and K.R. Barton. 2001. Effect of instrument 
attachment and other factors on foraging trip duration and nesting success of Adélie penguins. Condor 103: 481-490.

Broderick, A.C. and B.J. Godley. 1999. Effect of tagging marine turtles on nesting behavior and reproductive success. Anim. Behav. 58: 587-591.

Bubb, D.H., M.C. Lucas, T.J. Thom, and P. Rycroft. 2002. The potential use of PIT telemetry for identifying and tracking crayfish in their natural environment. Hydrobiologia 483: 225-230.

Burke, B.J. and M.A. Jepson. 2006. Performance of passive integrated transponder tags and radio tags in determining dam passage behavior of adult Chinook salmon and steelhead. N. Am. J. Fish. Manage. 26(3): 742-752.

Buzby, K. and L. Deegan. 1999. Retention of anchor and passive integrated transponder tags by arctic grayling. N. Am. J. Fish. Manage. 19(4): 1147-1150.

Camper, J.D. and J.R. Dixon. 1988. Evaluation of a microchip marking system for amphibians and reptiles. Texas Parks and Wildl. Dept., Res. Publ. 7100: 1-22.

Carver, A.V., L.W. Burger, and L.A. Brennan. 1999. Passive integrated transponders and patagial tag markers for northern bobwhite chicks. J. Wildl. Manage. 63: 162166.

Clugston, J.P. 1996. Retention of T-bar anchor tags and passive integrated transponder tags by Gulf sturgeons. N. Am. J. Fish. Manage. 16(3): 682-685.

Dare, M.R. 2003. Mortality and long-term retention of passive integrated transponder tags by spring Chinook salmon. N. Am. J. Fish. Manage. 23: 1015-1019.

Das Mahaptera, K., B. Gjerde, P.V.G.K. Reddy, M. Sahoo, R.K. Jana, and M. Rye. 2001. Tagging: on the use of passive integrated transponder (PIT) tags for the identification of fish. Aquacult. Res. 32: 47-50.

Donaldson, W.E., D. Schmidt, L. Watson, and D. Pengilly. 1992. Development of a technique to tag adult red king crab with passive integrated transponder tags. J. Shellfish Res. 11: 91-94.

Elbin, S.B. and J. Burger. 1994. In my experience: implantable microchips for individual identification in wild and captive populations. Wildl. Soc. Bull. 22 (4): 677-683.

Fagerstone, K.A., and B.E. Johns. 1987. Transponders as permanent identification markers for domestic ferrets, black-footed ferrets, and other wildlife. J. Wildl. Manage. 51: 294-297. 
Feldheim, K.A., S.H. Gruber, J.R.C. de Marignac, and M.V. Ashley. 2002. Genetic tagging to determine passive integrated transponder tag loss in lemon sharks. J. Fish Biol. 61: 1309-1313.

Galimberti, F., S. Sanvito, and L. Boitani. 2000. Marking of southern elephant seals with passive integrated transponders. Mar. Mammal Sci. 16(2): 500-504.

Gibbons, J.W., and K.M. Andrews. 2004. PIT tagging: simple technology at its best. Bioscience 54(5): 447-454.

Harvey, W.D. and D.L. Campbell. 1989. Retention of passive integrated transponder tags in largemouth bass brood fish. Prog. Fish-Cult. 51: 164-166.

Jemison, S.C., L.A. Bishop, P.G. May, and T.M. Farell. 1995. Impact of PIT-tags on growth and movement of the rattlesnake, Sistrurus miliarius. J. Herpetol. 29: $129-132$.

Jenkins, W.E. and T.I.J. Smith. 1990. Use of PIT tags to individually identify striped bass and red drum brood stocks. Am. Fish. Soc. Symp. 7: 341-345.

Knights, B. and M. White. 1998. Enhancing immigration and recruitment of eels: the uses of passes and associated trapping systems. Fish. Manage. Ecol. 5: 459-471

Matthews, K.R. 2003. Response of mountain yellow-legged frogs, Rana muscosa, to short distance translocation. J. Herpetol. 37: 621-626.

McCormick, M.I. and S. Smith. 2004. Efficacy of passive integrated transponder tags to determine spawning-site visitations by a tropical fish. Coral Reefs 23 (4): 570577.

McCutcheon, C.S., E.F. Prentice, and D.L. Park. 1994. Passive monitoring of migrating adult steelhead with PIT tags. N. Am. J. Fish. Manage. 14: 220-223.

McFarlane, G.A., R.S. Wydoski, and E.D. Prince. 1990. Historical review of the development of external tags and marks. Am. Fish. Soc. Symp. 7: 9-29.

Moore, A. 1992. Passive integrated transponder tagging of channel catfish. The Prog. Fish-Cult. 54: 125-127.

Morrison, W.E., and D.H. Secor. 2003. Demographic attributes of yellow-phase American eels (Anguilla rostrata) in the Hudson River estuary. Can. J. Fish. Aquat. Sci. 60: 1487-1501.

Neubaum, D.J., M.A. Neubaum, L.E. Ellison, and T.J. O’Shea. 2005. Survival and condition of big brown bats (Eptesicus fuscus) after radiotagging. J. Mammal. 86(1): 95-98. 
Ombredane, D., J.L. Bagliniere, and F. Marchand. 1998. The effects of passive integrated transponder tags on brown trout (Salmo trutta L.) and their use for studying movement in a small river. Hydrobiologia 371/372: 99-106.

Onders, R.J., S.D. Mims, C. Wang, and W.D. Pearson. 2001. Reservoir ranching of paddlefish. N. Am. J. Aquacult. 63: 179-190.

Parker, S.J. and P.S. Rankin. 2003. Tag location and retention in black rockfish: feasibility of using PIT in a wild marine species. N. Am. J. Fish. Manage. 23 (3): 993-996.

Prentice, E. and D. Park. 1984. A study to determine the biological feasibility of a new fish tagging system. Annual report 1983-1984. Project No. 1983-01900, 42 electronic pages (DOE/BP348).

Prentice, E.F., T.A. Flagg, and C.S. McCutcheon. 1990a. Feasibility of using implantable passive integrated transponder (PIT) tags in salmonids. Am. Fish. Soc. Symp. 7: 317-322.

Prentice, E.F., T.A. Flagg, C.S. McCutcheon, and D.F. Brastow. 1990b. PIT-tag monitoring systems for hydroelectric dams and fish hatcheries. Am. Fish. Soc. Symp. 7: 323-334.

Quintella, B.R., N.O. Andrade, R. Espanhol, and P.R. Almeida. 2005. The use of PIT tag telemetry to study movements of ammocoetes and metamorphosing sea lampreys in river beds. J. Fish Biol. 66: 97-106.

Ruetz, C.R. III, B.M. Earl, and S.L. Kohler. 2006. Evaluating passive integrated transponder tags for marking mottled sculpins: effects on growth and mortality. Trans. Am. Fish. Soc. 135 (6): 1456-1461

Schwarz, C.J. and W.T. Stobo. 1999. Estimation and effects of tag-misread rates in capture-recapture studies. Can. J. Fish. Aquat. Sci. 56: 551-559.

Shelton, A.O., D.A. Woodby, K. Hebert, and J.D. Witman. 2006. Evaluating age determination and spatial patterns of growth in red sea urchins in southeast Alaska. Trans. Am. Fish. Soc. 135 (6): 1670-1680.

Smithson, E.B. and C.E. Johnston. 1999. Movement patterns of stream fishes in a Ouachita highlands stream: an examination of the restricted movement paradigm. Trans. Am. Fish. Soc. 128 (5): 847-853.

Stobo, W.T. and J.K. Horne. 1994. Tag loss in grey seals (Halichoerus grypus) and potential effects on population estimates. Can. J. Zool. 72: 555-561. 
Thomas, J.C. 2006. American eel behavioral patterns in Silver Lake, Dover, Delaware. Master's Thesis, Delaware State University, Dover, Delaware.

Verdon, R., and D. Desrochers. 2003. Upstream migratory movements of American eel Anguilla rostrata between the Beauharnois and Moses-Saunders power dams on the St. Lawrence River. Am. Fish. Soc. Symp. 33: 139-151.

Verdon, R., D. Desrochers, and P. Dumont. 2003. Recruitment of American eels in the Richelieu River and Lake Champlain: provision of upstream passage as a regional-scale solution to a large-scale problem. Am. Fish. Soc. Symp. 33: 125138. 
Table 3-1: Synthesis of PIT tag retention rates from American eel studies.

\begin{tabular}{cccccc}
\hline Study & Location of Study & Duration & Eel Length (mm) & Tag Location & $\begin{array}{c}\text { Tag } \\
\text { Retention }\end{array}$ \\
\hline Thomas (2006) & Laboratory & 6 months & $\geq 500$ & $\begin{array}{c}\text { Dorsal } \\
\text { musculature }\end{array}$ & $100 \%$ \\
Morrison and Secor (2003) & Hudson River, NY & 2 months & Mean $=457$ & Visceral cavity & $89 \%$ \\
$\begin{array}{c}\text { Verdon and Desrochers } \\
\text { (2003) }\end{array}$ & St. Lawrence River, NY & $1998-1999$ & $\begin{array}{c}\text { Mean }=471.7(1998) \\
\text { Mean }=468.7(1999)\end{array}$ & Behind the head & $98 \%$ \\
Verdon et al. (2003) & Richelieu River, Quebec & $1997-1999$ & Mean $=379.7$ & Dorsal & $93.9 \%$ \\
\hline
\end{tabular}

Table 3-2: PIT tag retention in small American eels (205 - $370 \mathrm{~mm}$ total length) during a 9 week laboratory study $(\mathrm{P}=$ tag present, $\mathrm{H}=$ head tag shed, $\mathrm{D}=$ dorsal tag shed, and $\mathrm{A}=$ abdominal tag shed).

\begin{tabular}{cccccccccc}
\hline & \multicolumn{1}{c}{ Week } \\
\cline { 2 - 9 } Length (mm) & 1 & 2 & 3 & 4 & 5 & 6 & 7 & 8 & 9 \\
\hline 205 & $\mathrm{P}$ & $\mathrm{P}$ & $\mathrm{P}$ & $\mathrm{P}$ & $\mathrm{P}$ & $\mathrm{P}$ & $\mathrm{P}$ & $\mathrm{P}$ & $\mathrm{P}$ \\
270 & $\mathrm{H}$ & - & - & - & - & - & - & - & - \\
275 & $\mathrm{P}$ & $\mathrm{P}$ & $\mathrm{P}$ & $\mathrm{P}$ & $\mathrm{P}$ & $\mathrm{P}$ & $\mathrm{P}$ & $\mathrm{P}$ & $\mathrm{P}$ \\
280 & $\mathrm{P}$ & $\mathrm{P}$ & $\mathrm{P}$ & $\mathrm{P}$ & $\mathrm{P}$ & $\mathrm{P}$ & $\mathrm{P}$ & $\mathrm{P}$ & $\mathrm{P}$ \\
295 & $\mathrm{P}$ & $\mathrm{P}$ & $\mathrm{P}$ & $\mathrm{P}$ & $\mathrm{P}$ & $\mathrm{P}$ & $\mathrm{P}$ & $\mathrm{P}$ & $\mathrm{P}$ \\
300 & $\mathrm{P}$ & $\mathrm{P}$ & $\mathrm{P}$ & $\mathrm{P}$ & $\mathrm{P}$ & $\mathrm{P}$ & $\mathrm{P}$ & $\mathrm{P}$ & $\mathrm{P}$ \\
300 & $\mathrm{P}$ & $\mathrm{P}$ & $\mathrm{P}$ & $\mathrm{P}$ & $\mathrm{P}$ & $\mathrm{P}$ & $\mathrm{P}$ & $\mathrm{P}$ & $\mathrm{P}$ \\
305 & $\mathrm{P}$ & $\mathrm{P}$ & $\mathrm{P}$ & $\mathrm{P}$ & $\mathrm{P}$ & $\mathrm{P}$ & $\mathrm{P}$ & $\mathrm{P}$ & $\mathrm{P}$ \\
310 & $\mathrm{P}$ & $\mathrm{P}$ & $\mathrm{P}$ & $\mathrm{P}$ & $\mathrm{P}$ & $\mathrm{P}$ & $\mathrm{P}$ & $\mathrm{P}$ & $\mathrm{P}$ \\
310 & $\mathrm{P}$ & $\mathrm{P}$ & $\mathrm{P}$ & $\mathrm{P}$ & $\mathrm{P}$ & $\mathrm{P}$ & $\mathrm{P}$ & $\mathrm{P}$ & $\mathrm{P}$ \\
330 & $\mathrm{P}$ & $\mathrm{P}$ & $\mathrm{P}$ & $\mathrm{P}$ & $\mathrm{P}$ & $\mathrm{P}$ & $\mathrm{P}$ & $\mathrm{P}$ & $\mathrm{P}$ \\
340 & $\mathrm{H}$ & - & - & - & - & - & - & - & - \\
340 & $\mathrm{P}$ & $\mathrm{P}$ & $\mathrm{P}$ & $\mathrm{P}$ & $\mathrm{P}$ & $\mathrm{P}$ & $\mathrm{P}$ & $\mathrm{P}$ & $\mathrm{P}$ \\
340 & $\mathrm{P}$ & $\mathrm{P}$ & $\mathrm{P}$ & $\mathrm{P}$ & $\mathrm{P}$ & $\mathrm{P}$ & $\mathrm{P}$ & $\mathrm{P}$ & $\mathrm{P}$ \\
345 & $\mathrm{P}$ & $\mathrm{P}$ & $\mathrm{P}$ & $\mathrm{P}$ & $\mathrm{P}$ & $\mathrm{P}$ & $\mathrm{P}$ & $\mathrm{P}$ & $\mathrm{P}$ \\
345 & $\mathrm{P}$ & $\mathrm{P}$ & $\mathrm{P}$ & $\mathrm{P}$ & $\mathrm{P}$ & $\mathrm{P}$ & $\mathrm{P}$ & $\mathrm{P}$ & $\mathrm{P}$ \\
350 & $\mathrm{P}$ & $\mathrm{P}$ & $\mathrm{P}$ & $\mathrm{P}$ & $\mathrm{P}$ & $\mathrm{P}$ & $\mathrm{P}$ & $\mathrm{P}$ & $\mathrm{P}$ \\
370 & $\mathrm{P}$ & $\mathrm{P}$ & $\mathrm{P}$ & $\mathrm{P}$ & $\mathrm{P}$ & $\mathrm{P}$ & $\mathrm{P}$ & $\mathrm{P}$ & $\mathrm{P}$ \\
\hline
\end{tabular}




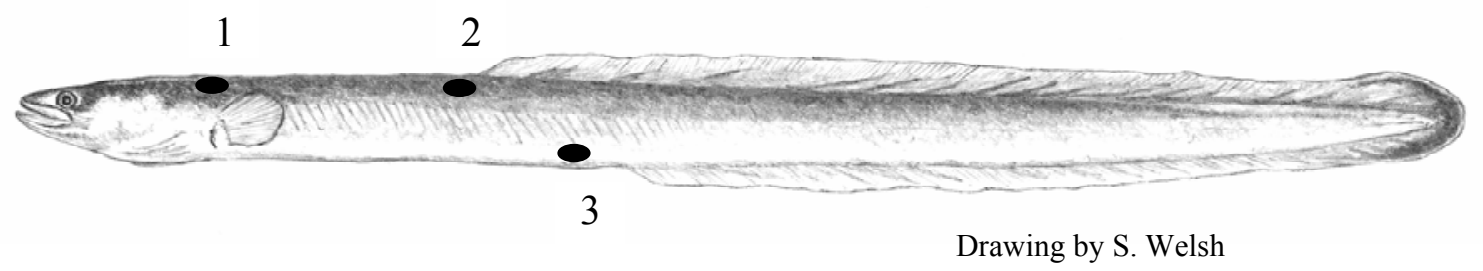

Figure 3-1: PIT tag location for American eels including 1) dorsal musculature behind the head, 2) dorsal musculature near the dorsal fin origin, and 3) the abdominal cavity. 


\section{Appendix A: Pictures of the Millville Dam Eel Ladder}

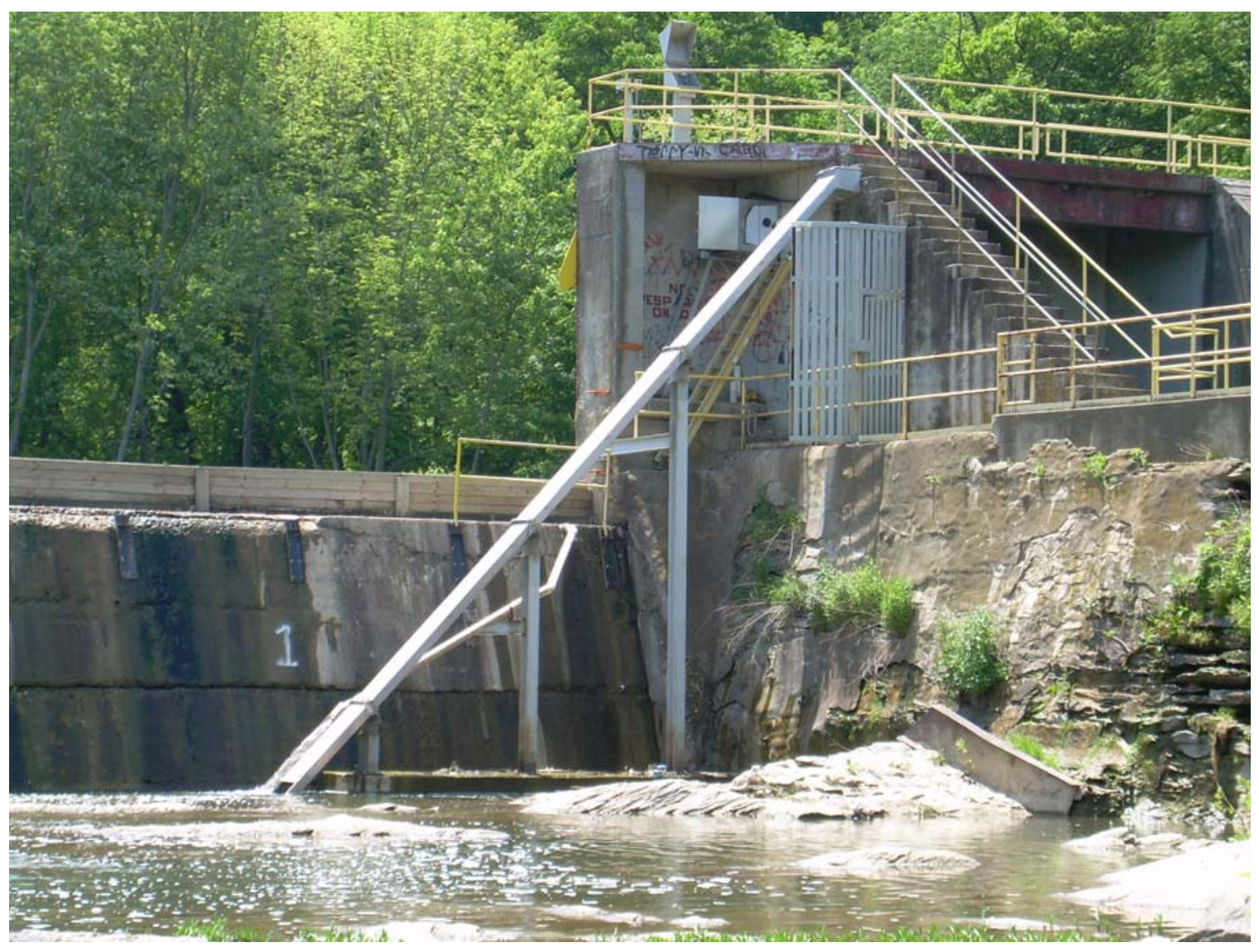

Millville Dam eel ladder on the Shenandoah River (designed by Milieu, Inc. Canada). Photo by J.L. Zimmerman 

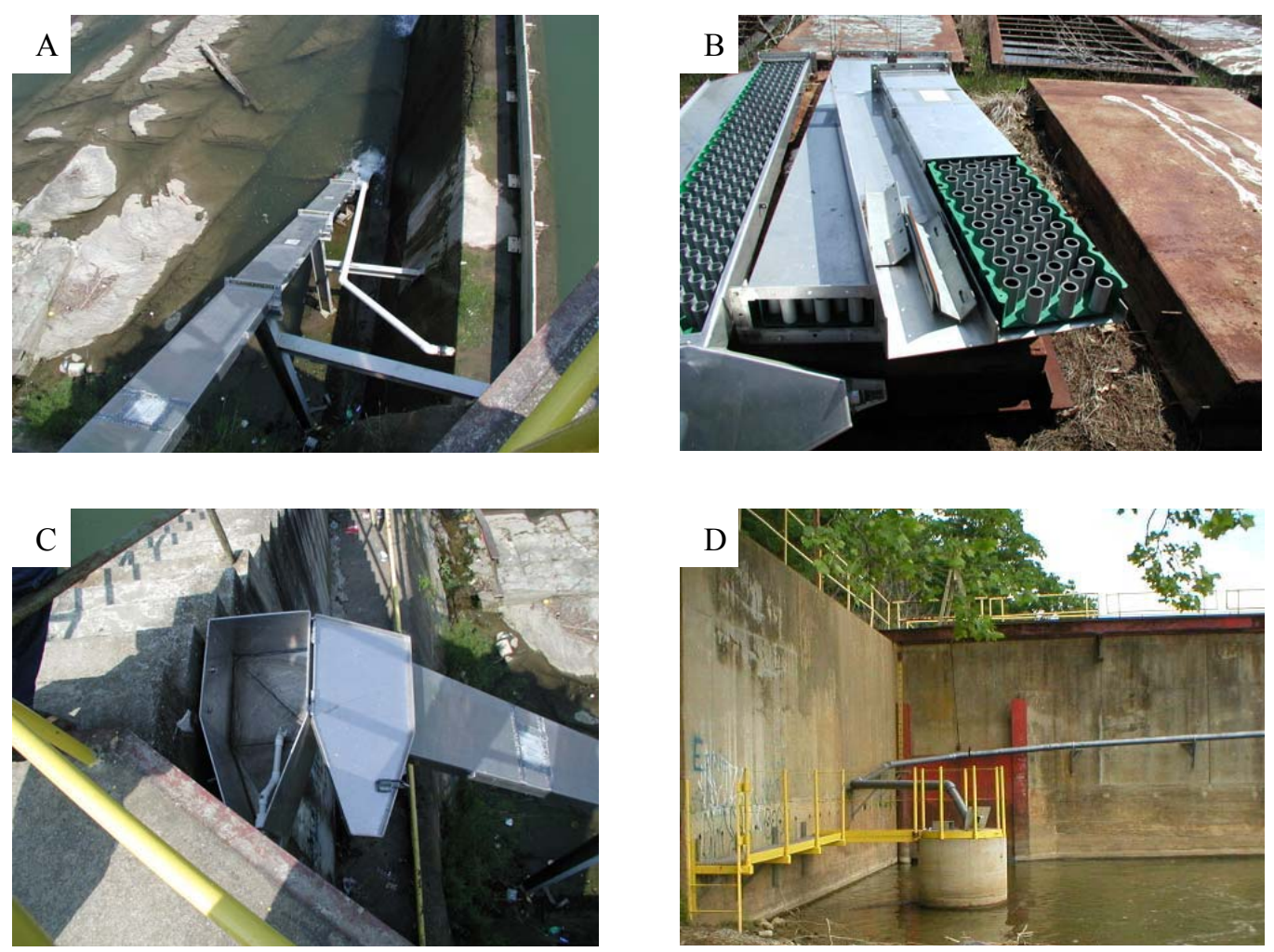

Design specifications of the Millville Dam eel ladder (A) flashboard placement and attraction flow, (B) internal design, (C) source of facilitation flow, and (D) upstream collection tank, which contains the mesh nets. Photos from Hildebrand (2005).

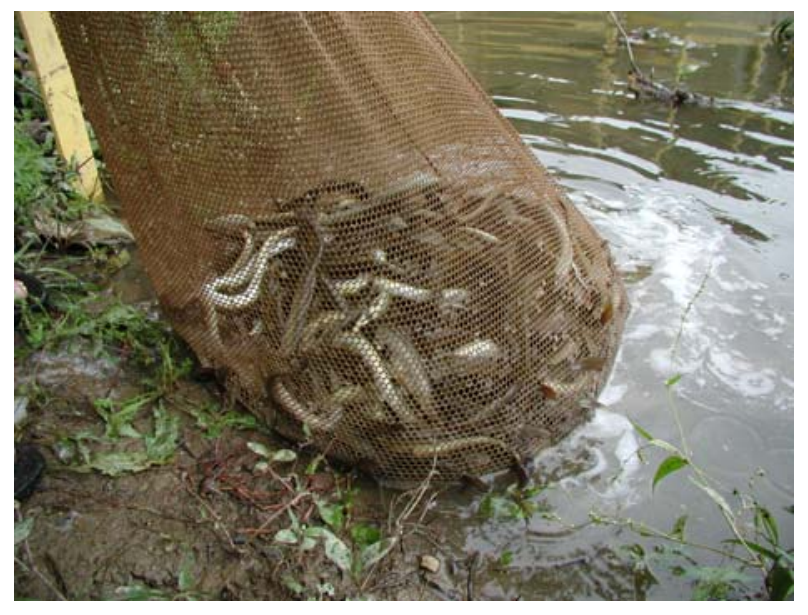

Mesh net used to collect eels in the holding tank. Photo by J.L. Zimmerman. 


\section{Appendix B: PIT Tagging Pictures}

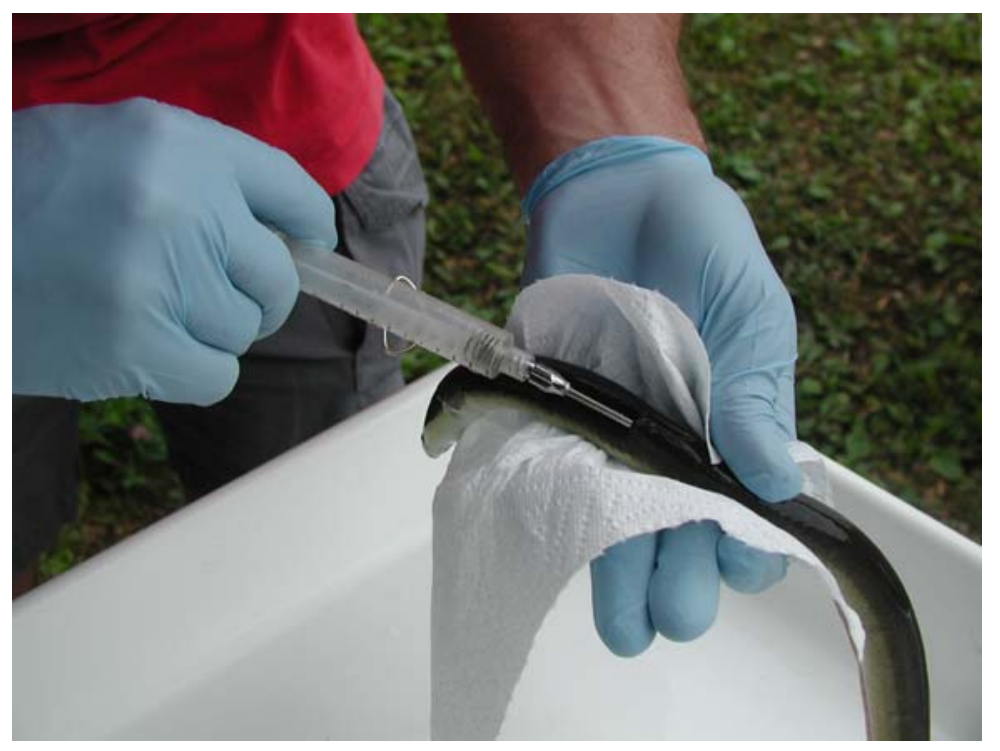

Pit tagging an American eel in the dorsal fin origin. Photo by J.L. Zimmerman

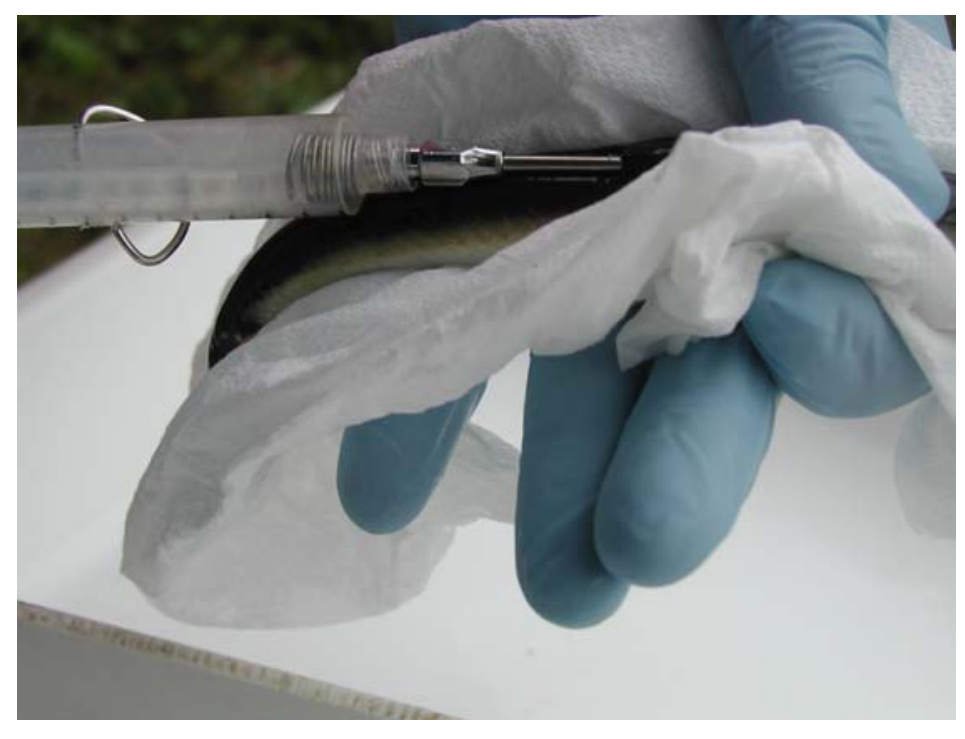

Close-up of an American eel being PIT tagged in the dorsal fin origin. Photo by J.L. Zimmerman 


\section{Appendix C: Parasite, Length, and Ageing Data}

\begin{tabular}{|c|c|c|c|c|c|c|c|}
\hline Length & $\begin{array}{l}\text { Nematode } \\
\text { Present }\end{array}$ & Intensity & Age & $\begin{array}{c}\text { Swim } \\
\text { Bladder } \\
\text { Transparancy }\end{array}$ & $\begin{array}{l}\text { Swim } \\
\text { Bladder } \\
\text { Size }\end{array}$ & $\begin{array}{l}\text { Exudate/ } \\
\text { Pigment }\end{array}$ & $\begin{array}{l}\text { SDI } \\
\text { Score }\end{array}$ \\
\hline 200 & NO & 0 & - & - & - & - & - \\
\hline 215 & NO & 0 & - & - & - & - & - \\
\hline 224 & NO & 0 & - & - & - & - & - \\
\hline 231 & $\mathrm{NO}$ & 0 & - & - & - & - & - \\
\hline 233 & NO & 0 & - & - & - & - & - \\
\hline 243 & $\mathrm{NO}$ & 0 & - & - & - & - & - \\
\hline 244 & $\mathrm{NO}$ & 0 & 4 & 0 & 0 & 0 & 0 \\
\hline 250 & $\mathrm{NO}$ & 0 & - & - & - & - & - \\
\hline 253 & $\mathrm{NO}$ & 0 & - & - & - & - & - \\
\hline 254 & $\mathrm{NO}$ & 0 & - & - & - & - & - \\
\hline 255 & $\mathrm{NO}$ & 0 & 5 & 0 & 0 & 2 & 2 \\
\hline 256 & NO & 0 & - & - & - & - & - \\
\hline 256 & NO & 0 & - & - & - & - & - \\
\hline 258 & $\mathrm{NO}$ & 0 & - & 0 & 0 & 0 & 0 \\
\hline 259 & $\mathrm{NO}$ & 0 & - & 0 & 0 & 0 & 0 \\
\hline 265 & NO & 0 & - & - & - & - & - \\
\hline 266 & NO & 0 & - & 0 & 0 & 0 & 0 \\
\hline 269 & NO & 0 & - & 0 & 0 & 0 & 0 \\
\hline 269 & $\mathrm{NO}$ & 0 & - & 0 & 0 & 0 & 0 \\
\hline 276 & $\mathrm{NO}$ & 0 & - & - & - & - & - \\
\hline 277 & $\mathrm{NO}$ & 0 & 9 & - & - & - & - \\
\hline 278 & NO & 0 & 6 & 0 & 0 & 0 & 0 \\
\hline 279 & $\mathrm{NO}$ & 0 & - & - & - & - & - \\
\hline 279 & NO & 0 & 4 & 0 & 0 & 1 & 1 \\
\hline 280 & NO & 0 & - & - & - & - & - \\
\hline 280 & NO & 0 & - & 0 & 0 & 0 & 0 \\
\hline 282 & $\mathrm{NO}$ & 0 & 7 & - & - & - & - \\
\hline 282 & $\mathrm{NO}$ & 0 & - & - & - & - & - \\
\hline 282 & NO & 0 & 7 & 0 & 0 & 2 & 2 \\
\hline 284 & $\mathrm{NO}$ & 0 & - & - & - & - & - \\
\hline 285 & $\mathrm{NO}$ & 0 & 7 & 0 & 0 & 0 & 0 \\
\hline 285 & NO & 0 & - & 0 & 0 & 0 & 0 \\
\hline 285 & NO & 0 & - & 0 & 0 & 0 & 0 \\
\hline
\end{tabular}




\begin{tabular}{|c|c|c|c|c|c|c|c|}
\hline Length & $\begin{array}{l}\text { Nematode } \\
\text { Present }\end{array}$ & Intensity & Age & $\begin{array}{c}\text { Swim } \\
\text { Bladder } \\
\text { Transparancy }\end{array}$ & $\begin{array}{l}\text { Swim } \\
\text { Bladder } \\
\text { Size }\end{array}$ & $\begin{array}{l}\text { Exudate/ } \\
\text { Pigment }\end{array}$ & $\begin{array}{c}\text { SDI } \\
\text { Score }\end{array}$ \\
\hline 286 & NO & 0 & - & - & - & - & - \\
\hline 286 & $\mathrm{NO}$ & 0 & - & 0 & 0 & 0 & 0 \\
\hline 288 & $\mathrm{NO}$ & 0 & - & - & - & - & - \\
\hline 289 & $\mathrm{NO}$ & 0 & 5 & - & - & - & - \\
\hline 289 & $\mathrm{NO}$ & 0 & 5 & 1 & 0 & 0 & 1 \\
\hline 290 & $\mathrm{NO}$ & 0 & 4 & - & - & - & - \\
\hline 290 & NO & 0 & - & - & - & - & - \\
\hline 290 & NO & 0 & 7 & 1 & 0 & 1 & 2 \\
\hline 290 & $\mathrm{NO}$ & 0 & 7 & 0 & 0 & 1 & 1 \\
\hline 291 & $\mathrm{NO}$ & 0 & - & 0 & 0 & 0 & 0 \\
\hline 293 & $\mathrm{NO}$ & 0 & - & - & - & - & - \\
\hline 294 & NO & 0 & - & 0 & 0 & 0 & 0 \\
\hline 295 & $\mathrm{NO}$ & 0 & - & - & - & - & - \\
\hline 295 & NO & 0 & - & - & - & - & - \\
\hline 296 & $\mathrm{NO}$ & 0 & - & 0 & 0 & 0 & 0 \\
\hline 299 & $\mathrm{NO}$ & 0 & 4 & 0 & 0 & 0 & 0 \\
\hline 299 & $\mathrm{NO}$ & 0 & 7 & 0 & 0 & 0 & 0 \\
\hline 299 & NO & 0 & - & 0 & 0 & 0 & 0 \\
\hline 300 & NO & 0 & - & - & - & - & - \\
\hline 301 & NO & 0 & - & - & - & - & - \\
\hline 301 & NO & 0 & - & 0 & 0 & 0 & 0 \\
\hline 302 & $\mathrm{NO}$ & 0 & - & 0 & 0 & 0 & 0 \\
\hline 302 & $\mathrm{NO}$ & 0 & - & 0 & 0 & 2 & 2 \\
\hline 303 & $\mathrm{NO}$ & 0 & - & - & - & - & - \\
\hline 303 & $\mathrm{NO}$ & 0 & - & - & - & - & - \\
\hline 304 & $\mathrm{NO}$ & 0 & 7 & 0 & 0 & 0 & 0 \\
\hline 308 & $\mathrm{NO}$ & 0 & 10 & 1 & 0 & 1 & 2 \\
\hline 309 & $\mathrm{NO}$ & 0 & - & - & - & - & - \\
\hline 309 & $\mathrm{NO}$ & 0 & - & - & - & - & - \\
\hline 310 & NO & 0 & - & - & - & - & - \\
\hline 310 & NO & 0 & - & - & - & - & - \\
\hline 310 & NO & 0 & - & - & - & - & - \\
\hline 310 & NO & 0 & - & - & - & - & - \\
\hline 311 & NO & 0 & - & - & - & - & - \\
\hline 311 & NO & 0 & 7 & 0 & 0 & 0 & 0 \\
\hline 316 & $\mathrm{NO}$ & 0 & - & 0 & 0 & 0 & 0 \\
\hline
\end{tabular}




\begin{tabular}{|c|c|c|c|c|c|c|c|}
\hline Length & $\begin{array}{l}\text { Nematode } \\
\text { Present }\end{array}$ & Intensity & Age & $\begin{array}{c}\text { Swim } \\
\text { Bladder } \\
\text { Transparancy }\end{array}$ & $\begin{array}{l}\text { Swim } \\
\text { Bladder } \\
\text { Size }\end{array}$ & $\begin{array}{l}\text { Exudate/ } \\
\text { Pigment }\end{array}$ & $\begin{array}{l}\text { SDI } \\
\text { Score }\end{array}$ \\
\hline 317 & NO & 0 & - & - & - & - & - \\
\hline 320 & $\mathrm{NO}$ & 0 & - & - & - & - & - \\
\hline 320 & $\mathrm{NO}$ & 0 & - & - & - & - & - \\
\hline 320 & $\mathrm{NO}$ & 0 & - & - & - & - & - \\
\hline 320 & $\mathrm{NO}$ & 0 & 5 & 1 & 0 & 1 & 2 \\
\hline 320 & NO & 0 & 10 & 1 & 0 & 1 & 2 \\
\hline 324 & NO & 0 & - & - & - & - & - \\
\hline 324 & NO & 0 & 6 & 0 & 0 & 1 & 1 \\
\hline 325 & $\mathrm{NO}$ & 0 & - & - & - & - & - \\
\hline 326 & NO & 0 & - & - & - & - & - \\
\hline 326 & NO & 0 & - & - & - & - & - \\
\hline 326 & $\mathrm{NO}$ & 0 & - & - & - & - & - \\
\hline 326 & $\mathrm{NO}$ & 0 & - & 1 & 0 & 1 & 2 \\
\hline 328 & NO & 0 & - & 0 & 0 & 0 & 0 \\
\hline 329 & $\mathrm{NO}$ & 0 & - & - & - & - & - \\
\hline 330 & NO & 0 & 6 & - & - & - & - \\
\hline 330 & $\mathrm{NO}$ & 0 & - & 0 & 0 & 0 & 0 \\
\hline 331 & $\mathrm{NO}$ & 0 & 7 & - & - & - & - \\
\hline 331 & NO & 0 & - & - & - & - & - \\
\hline 331 & NO & 0 & - & - & - & - & - \\
\hline 334 & NO & 0 & - & - & - & - & - \\
\hline 335 & NO & 0 & - & - & - & - & - \\
\hline 335 & $\mathrm{NO}$ & 0 & - & - & - & - & - \\
\hline 335 & $\mathrm{NO}$ & 0 & - & - & - & - & - \\
\hline 336 & YES & 1 & - & - & - & - & - \\
\hline 338 & $\mathrm{NO}$ & 0 & - & - & - & - & - \\
\hline 338 & $\mathrm{NO}$ & 0 & - & - & - & - & - \\
\hline 339 & $\mathrm{NO}$ & 0 & - & - & - & - & - \\
\hline 339 & $\mathrm{NO}$ & 0 & - & - & - & - & - \\
\hline 339 & NO & 0 & - & - & - & - & - \\
\hline 340 & NO & 0 & 5 & - & - & - & - \\
\hline 340 & $\mathrm{NO}$ & 0 & - & - & - & - & - \\
\hline 340 & NO & 0 & - & - & - & - & - \\
\hline 340 & $\mathrm{NO}$ & 0 & - & - & - & - & - \\
\hline 340 & $\mathrm{NO}$ & 0 & - & - & - & - & - \\
\hline 341 & $\mathrm{NO}$ & 0 & - & - & - & - & - \\
\hline
\end{tabular}




\begin{tabular}{|c|c|c|c|c|c|c|c|}
\hline Length & $\begin{array}{l}\text { Nematode } \\
\text { Present }\end{array}$ & Intensity & Age & $\begin{array}{c}\text { Swim } \\
\text { Bladder } \\
\text { Transparancy }\end{array}$ & $\begin{array}{l}\text { Swim } \\
\text { Bladder } \\
\text { Size }\end{array}$ & $\begin{array}{l}\text { Exudate/ } \\
\text { Pigment }\end{array}$ & $\begin{array}{c}\text { SDI } \\
\text { Score }\end{array}$ \\
\hline 342 & NO & 0 & - & - & - & - & - \\
\hline 342 & $\mathrm{NO}$ & 0 & - & - & - & - & - \\
\hline 343 & $\mathrm{NO}$ & 0 & - & - & - & - & - \\
\hline 343 & $\mathrm{NO}$ & 0 & - & - & - & - & - \\
\hline 344 & $\mathrm{NO}$ & 0 & - & 0 & 0 & 1 & 1 \\
\hline 346 & $\mathrm{NO}$ & 0 & - & - & - & - & - \\
\hline 346 & NO & 0 & - & - & - & - & - \\
\hline 347 & NO & 0 & - & - & - & - & - \\
\hline 347 & $\mathrm{NO}$ & 0 & - & - & - & - & - \\
\hline 347 & $\mathrm{NO}$ & 0 & 5 & 0 & 0 & 1 & 1 \\
\hline 348 & $\mathrm{NO}$ & 0 & - & - & - & - & - \\
\hline 349 & $\mathrm{NO}$ & 0 & - & - & - & - & - \\
\hline 349 & $\mathrm{NO}$ & 0 & - & 0 & 0 & 1 & 1 \\
\hline 350 & NO & 0 & - & - & - & - & - \\
\hline 350 & NO & 0 & - & 0 & 0 & 0 & 0 \\
\hline 351 & NO & 0 & - & - & - & - & - \\
\hline 351 & $\mathrm{NO}$ & 0 & - & - & - & - & - \\
\hline 352 & NO & 0 & - & - & - & - & - \\
\hline 352 & NO & 0 & - & - & - & - & - \\
\hline 354 & NO & 0 & - & - & - & - & - \\
\hline 355 & NO & 0 & - & - & - & - & - \\
\hline 355 & $\mathrm{NO}$ & 0 & - & - & - & - & - \\
\hline 355 & $\mathrm{NO}$ & 0 & - & - & - & - & - \\
\hline 356 & $\mathrm{NO}$ & 0 & - & - & - & - & - \\
\hline 356 & $\mathrm{NO}$ & 0 & - & - & - & - & - \\
\hline 358 & $\mathrm{NO}$ & 0 & - & - & - & - & - \\
\hline 360 & $\mathrm{NO}$ & 0 & - & - & - & - & - \\
\hline 360 & $\mathrm{NO}$ & 0 & - & - & - & - & - \\
\hline 361 & NO & 0 & - & - & - & - & - \\
\hline 361 & NO & 0 & - & - & - & - & - \\
\hline 361 & NO & 0 & - & - & - & - & - \\
\hline 362 & NO & 0 & - & - & - & - & - \\
\hline 362 & NO & 0 & - & - & - & - & - \\
\hline 362 & NO & 0 & - & - & - & - & - \\
\hline 362 & NO & 0 & - & 0 & 0 & 0 & 0 \\
\hline 364 & $\mathrm{NO}$ & 0 & - & - & - & - & - \\
\hline
\end{tabular}




\begin{tabular}{|c|c|c|c|c|c|c|c|}
\hline Length & $\begin{array}{l}\text { Nematode } \\
\text { Present }\end{array}$ & Intensity & Age & $\begin{array}{c}\text { Swim } \\
\text { Bladder } \\
\text { Transparancy }\end{array}$ & $\begin{array}{l}\text { Swim } \\
\text { Bladder } \\
\text { Size }\end{array}$ & $\begin{array}{l}\text { Exudate/ } \\
\text { Pigment }\end{array}$ & $\begin{array}{c}\text { SDI } \\
\text { Score }\end{array}$ \\
\hline 365 & NO & 0 & - & - & - & - & - \\
\hline 366 & $\mathrm{NO}$ & 0 & 6 & - & - & - & - \\
\hline 366 & $\mathrm{NO}$ & 0 & - & - & - & - & - \\
\hline 366 & $\mathrm{NO}$ & 0 & - & - & - & - & - \\
\hline 368 & $\mathrm{NO}$ & 0 & - & - & - & - & - \\
\hline 368 & $\mathrm{NO}$ & 0 & - & - & - & - & - \\
\hline 368 & NO & 0 & - & - & - & - & - \\
\hline 368 & NO & 0 & - & - & - & - & - \\
\hline 369 & $\mathrm{NO}$ & 0 & - & - & - & - & - \\
\hline 369 & $\mathrm{NO}$ & 0 & - & - & - & - & - \\
\hline 370 & NO & 0 & 7 & - & - & - & - \\
\hline 370 & $\mathrm{NO}$ & 0 & - & - & - & - & - \\
\hline 370 & $\mathrm{NO}$ & 0 & - & - & - & - & - \\
\hline 370 & NO & 0 & - & - & - & - & - \\
\hline 371 & $\mathrm{NO}$ & 0 & - & - & - & - & - \\
\hline 373 & $\mathrm{NO}$ & 0 & 8 & - & - & - & - \\
\hline 373 & $\mathrm{NO}$ & 0 & - & - & - & - & - \\
\hline 373 & NO & 0 & - & - & - & - & - \\
\hline 374 & NO & 0 & - & - & - & - & - \\
\hline 374 & NO & 0 & 8 & 1 & 0 & 0 & 1 \\
\hline 375 & NO & 0 & - & - & - & - & - \\
\hline 375 & $\mathrm{NO}$ & 0 & - & - & - & - & - \\
\hline 375 & $\mathrm{NO}$ & 0 & - & - & - & - & - \\
\hline 376 & $\mathrm{NO}$ & 0 & - & - & - & - & - \\
\hline 378 & $\mathrm{NO}$ & 0 & - & - & - & - & - \\
\hline 378 & $\mathrm{NO}$ & 0 & - & - & - & - & - \\
\hline 379 & NO & 0 & - & - & - & - & - \\
\hline 379 & $\mathrm{NO}$ & 0 & - & - & - & - & - \\
\hline 379 & $\mathrm{NO}$ & 0 & - & - & - & - & - \\
\hline 379 & NO & 0 & - & 1 & 0 & 1 & 2 \\
\hline 380 & NO & 0 & 5 & - & - & - & - \\
\hline 380 & NO & 0 & 7 & - & - & - & - \\
\hline 380 & NO & 0 & - & - & - & - & - \\
\hline 380 & NO & 0 & 6 & 0 & 0 & 1 & 1 \\
\hline 381 & NO & 0 & 4 & - & - & - & - \\
\hline 383 & $\mathrm{NO}$ & 0 & - & - & - & - & - \\
\hline
\end{tabular}




\begin{tabular}{|c|c|c|c|c|c|c|c|}
\hline Length & $\begin{array}{l}\text { Nematode } \\
\text { Present }\end{array}$ & Intensity & Age & $\begin{array}{c}\text { Swim } \\
\text { Bladder } \\
\text { Transparancy }\end{array}$ & $\begin{array}{l}\text { Swim } \\
\text { Bladder } \\
\text { Size }\end{array}$ & $\begin{array}{l}\text { Exudate/ } \\
\text { Pigment }\end{array}$ & $\begin{array}{l}\text { SDI } \\
\text { Score }\end{array}$ \\
\hline 386 & YES & 1 & - & - & - & - & - \\
\hline 387 & NO & 0 & - & - & - & - & - \\
\hline 388 & $\mathrm{NO}$ & 0 & 10 & - & - & - & - \\
\hline 389 & $\mathrm{NO}$ & 0 & - & - & - & - & - \\
\hline 390 & $\mathrm{NO}$ & 0 & - & - & - & - & - \\
\hline 390 & NO & 0 & - & - & - & - & - \\
\hline 390 & $\mathrm{NO}$ & 0 & - & - & - & - & - \\
\hline 390 & NO & 0 & - & 0 & 0 & 0 & 0 \\
\hline 390 & $\mathrm{NO}$ & 0 & - & 0 & 0 & 1 & 1 \\
\hline 391 & $\mathrm{NO}$ & 0 & - & - & - & - & - \\
\hline 391 & NO & 0 & - & - & - & - & - \\
\hline 392 & NO & 0 & - & - & - & - & - \\
\hline 392 & $\mathrm{NO}$ & 0 & - & - & - & - & - \\
\hline 394 & NO & 0 & - & - & - & - & - \\
\hline 394 & $\mathrm{NO}$ & 0 & - & - & - & - & - \\
\hline 394 & $\mathrm{NO}$ & 0 & - & - & - & - & - \\
\hline 395 & $\mathrm{NO}$ & 0 & - & - & - & - & - \\
\hline 396 & NO & 0 & - & - & - & - & - \\
\hline 398 & NO & 0 & 10 & - & - & - & - \\
\hline 400 & $\mathrm{NO}$ & 0 & - & - & - & - & - \\
\hline 400 & $\mathrm{NO}$ & 0 & - & - & - & - & - \\
\hline 402 & NO & 0 & - & - & - & - & - \\
\hline 402 & $\mathrm{NO}$ & 0 & - & - & - & - & - \\
\hline 404 & $\mathrm{NO}$ & 0 & - & - & - & - & - \\
\hline 405 & $\mathrm{NO}$ & 0 & - & - & - & - & - \\
\hline 405 & $\mathrm{NO}$ & 0 & - & 0 & 0 & 0 & 0 \\
\hline 406 & $\mathrm{NO}$ & 0 & 7 & - & - & - & - \\
\hline 407 & $\mathrm{NO}$ & 0 & - & - & - & - & - \\
\hline 407 & $\mathrm{NO}$ & 0 & - & - & - & - & - \\
\hline 408 & $\mathrm{NO}$ & 0 & 7 & - & - & - & - \\
\hline 408 & NO & 0 & - & - & - & - & - \\
\hline 408 & $\mathrm{NO}$ & 0 & - & - & - & - & - \\
\hline 413 & NO & 0 & - & - & - & - & - \\
\hline 415 & $\mathrm{NO}$ & 0 & - & - & - & - & - \\
\hline 418 & $\mathrm{NO}$ & 0 & - & 0 & 0 & 0 & 0 \\
\hline 419 & $\mathrm{NO}$ & 0 & - & - & - & - & - \\
\hline
\end{tabular}




\begin{tabular}{|c|c|c|c|c|c|c|c|}
\hline Length & $\begin{array}{c}\text { Nematode } \\
\text { Present }\end{array}$ & Intensity & Age & $\begin{array}{c}\text { Swim } \\
\text { Bladder } \\
\text { Transparancy }\end{array}$ & $\begin{array}{c}\text { Swim } \\
\text { Bladder } \\
\text { Size }\end{array}$ & $\begin{array}{l}\text { Exudate/ } \\
\text { Pigment }\end{array}$ & $\begin{array}{c}\text { SDI } \\
\text { Score }\end{array}$ \\
\hline 420 & YES & 1 & 11 & - & - & - & - \\
\hline 421 & YES & 1 & 8 & - & - & - & - \\
\hline 422 & $\mathrm{NO}$ & 0 & - & - & - & - & - \\
\hline 423 & $\mathrm{NO}$ & 0 & - & - & - & - & - \\
\hline 425 & $\mathrm{NO}$ & 0 & - & - & - & - & - \\
\hline 429 & $\mathrm{NO}$ & 0 & 6 & - & - & - & - \\
\hline 429 & $\mathrm{NO}$ & 0 & - & - & - & - & - \\
\hline 434 & $\mathrm{NO}$ & 0 & - & - & - & - & - \\
\hline 438 & $\mathrm{NO}$ & 0 & - & - & - & - & - \\
\hline 439 & $\mathrm{NO}$ & 0 & - & - & - & - & - \\
\hline 440 & $\mathrm{NO}$ & 0 & - & - & - & - & - \\
\hline 440 & $\mathrm{NO}$ & 0 & - & - & - & - & - \\
\hline 440 & $\mathrm{NO}$ & 0 & - & - & - & - & - \\
\hline 442 & $\mathrm{NO}$ & 0 & - & - & - & - & - \\
\hline 443 & $\mathrm{NO}$ & 0 & - & - & - & - & - \\
\hline 450 & $\mathrm{NO}$ & 0 & 9 & - & - & - & - \\
\hline 450 & $\mathrm{NO}$ & 0 & - & - & - & - & - \\
\hline 450 & $\mathrm{NO}$ & 0 & - & - & - & - & - \\
\hline 452 & $\mathrm{NO}$ & 0 & - & - & - & - & - \\
\hline 467 & $\mathrm{NO}$ & 0 & 8 & 0 & 0 & 0 & 0 \\
\hline 471 & $\mathrm{NO}$ & 0 & - & - & - & - & - \\
\hline 473 & YES & 1 & - & - & - & - & - \\
\hline 475 & $\mathrm{NO}$ & 0 & - & - & - & - & - \\
\hline 480 & $\mathrm{NO}$ & 0 & - & - & - & - & - \\
\hline 482 & $\mathrm{NO}$ & 0 & - & - & - & - & - \\
\hline 485 & NO & 0 & - & - & - & - & - \\
\hline 486 & $\mathrm{NO}$ & 0 & - & - & - & - & - \\
\hline 518 & $\mathrm{NO}$ & 0 & - & - & - & - & - \\
\hline 527 & $\mathrm{NO}$ & 0 & - & - & - & - & - \\
\hline
\end{tabular}

